Lexis Vol. XLIV (2) 2020: 525-574

\title{
El tuit como micropanfleto: el caso de la asunción del nuevo presidente mexicano*
}

\author{
María Gabriela Mazzuchino \\ Departamento Académico de Lenguas, \\ Instituto Tecnológico Autónomo de México (ITAM)
}

\section{RESUMEN}

Este artículo analiza discursivamente, desde un enfoque multidisciplinario y una visión amplia del hecho argumentativo, la dimensión polémica de un corpus extenso de tuits contrarios al expresidente mexicano Peña Nieto y al nuevo presidente, López Obrador, a raíz de la toma de protesta del último. Tomando distancia de los trabajos que asumen que en Twitter hay escasa o nula argumentación, y que lo que prevalece es la violencia, el análisis pone de manifiesto una cadena argumentativa reactiva, estructurada en argumentos no siempre entimemáticos, así como en otros recursos (muchos de ellos, visuales) que entroncan con la tradición polémica y panfletaria del siglo XIX mexicano, lo que nos lleva a describir al tuit como el sucedáneo actual del panfleto tradicional.

Palabras clave: Twitter, polémica, panfleto, Análisis del Discurso

\footnotetext{
* Este artículo es producto de la investigación que vengo desarrollando en el marco del Doctorado en Español: Lingüística, Literatura y Comunicación de la Universidad de Valladolid, bajo la dirección de la Dra. Micaela Carrera de la Red.
}

https://doi.org/10.18800/lexis.202002.005 
The Tweet as a Micro-pamphlet: The Case of the Inauguration of the New Mexican President

\begin{abstract}
This article analyzes the controversial dimension of a wide corpus of tweets that oppose to the former Mexican president Peña Nieto and the new president, López Obrador, in the context of the swearing-in ceremony of the latest, from a multidisciplinary approach and a broad vision of argumentation. Taking distance from the studies that assume that argumentation is not the preponderant on Twitter, and that violence is what prevails, our analysis reveals a reactive argumentative chain, structured in varied arguments, not just entimematic ones, as well as in other resources (many of them visual) that connect with the panfletary tradition of the Mexican 19th century, which leads us to describe the tweet as the current substitute of the traditional pamphlet.
\end{abstract}

Palabras clave: Twitter, controversy, pamphlet, Discourse Analysis

\title{
1. Introducción
}

Este trabajo indaga en las proyecciones del panfleto tradicional mexicano en los tuits actuales, distantes cronológicamente de aquel, y con una materialidad y condiciones de producción y de circulación diferentes, pero con profundas similitudes temáticas y estilísticas, entre otras que intentaremos desvelar en estas páginas.

Nuestro punto de partida es que Twitter constituye una "red de medios" o "colectivo hipermediático" (Fraticelli 2019: 47), más que una mera red social ${ }^{1}$, que, asimismo, muestra predilección por el "formato breve" y las "listas" (Scolari 2019), así como por el humor, en su articulación con modalidades que atraviesan históricamente diversos géneros, como la ironía, la parodia y la sátira

\footnotetext{
1 No obstante, por sencillez expositiva (dado que es corriente llamarlo así), usaremos indistintamente “Twitter” y "red social”. Para Scolari (2009), lo hipermediático está conformado por "la trama de reenvíos, hibridaciones y contaminaciones que la tecnología digital, al reducir todas las textualidades a una masa de bits, permite articular dentro del ecosistema de bits [...] En un contexto donde reinan la fragmentación y la rapidez de consumo".
} 
(aspecto que señalamos ya en Mazzuchino 2018 y 2019, y que fue observado por Pano Alamán y Mancera Rueda 2014).

Concebir a los tuits como proyecciones del panfleto puede parecer descabellado, pero varios trabajos previos (como Amossy 2011 y Paveau 2015) abordan diversas producciones de Internet, como los comentarios en notas periodísticas, en foros, en Facebook o en Twitter mismo, desde una concepción no dialéctica ni logicista de la argumentación y en el marco de la revalorización de la polémica impulsada por el Análisis del Discurso francés (en especial, por Plantin 2012 y Amossy 2017). Ya Hastings (2009) avizoró la posibilidad de que los discursos digitales abonaran en la actualidad la tradición erística y vituperativa, cuestión en la que se detiene Olave (2019), a partir de otras fuentes, para estudiar "el retorno" de la erística, a la que define como "discordia pública” y como una "dimensión transversal" a la retórica y la dialéctica. Al respecto, aún no podemos pronunciarnos sobre si la erística es lo central en Twitter; buena parte de los estudios previos que enfatizan su carácter "violento" parecen inclinarse por esta posibilidad, pero en nuestro corpus hallamos una prevalencia de la polémica, que siempre es pública (Plantin 2016: 76) y que plantea el disenso de modo no siempre explícito ni virulento, mediante la argumentación cotidiana (Amossy 2011; Plantin 2012; Walton 1989, 1992).

Desde esa concepción más flexible de argumentación, que admite recursos condenados por los enfoques centrados en la persuasión y la búsqueda del consenso, aquí defendemos que los tuits pueden ser argumentativos y, claro está, polémicos, si lo esencial en ellos - de modo similar a lo que ocurría con el panfleto- es manifestar el desacuerdo, confrontar posturas muchas veces irreconciliables (Plantin 2004), e incluso "producir e incrementar los desacuerdos, más que resolverlos" (Plantin 2012: 300, similar a Angenot, 2016: 43)², y no

\footnotetext{
Amossy (2016: 28) introduce el concepto de "dicotomización”, que define como “exacerbación de las oposiciones" en el sentido de división social, que también puede ponerse en relación con las categorías de "afiliación exacerbada" y de "refractariedad" propuestas por Kaul de Marlangeon y Cordisco (2014).
} 
el debate racional de ideas en virtud de pruebas "razonables" (como en la propuesta de Toulmin [1958] 2003).

Nuestro análisis discursivo surge de una reflexión sobre los vínculos entre los panfletos, esos "pasquines", hojas sueltas o libelos críticos, subjetivos, pasionales y aun injuriosos — por algo Courier (1936) comenta que se los llamaba "veneno impreso", y Picatto (2003: 155), "letreros inmundos"-, que buscaban exponer públicamente las faltas del poderoso, muchas veces conjugando el tono vitriólico con el humor, y transmitiendo una visión inconformista. Al igual que otras formas de la prensa, como los periódicos, diarios y revistas (Alonso 2003: 8), el panfleto estaba dotado de carácter político, pues "abrió un campo para la inscripción y el ejercicio de las políticas en pugna” (Rojas 2010: 88), en un contexto de tensión: el de los conflictos independentistas. De modo similar, como esperamos demostrar, la tónica de los tuits analizados es la contradicción y en ocasiones el enfrentamiento y la denuncia, en un momento crucial de la política mexicana.

Por ello, postulamos que, en la actualidad, los tuits construyen un contradiscurso sustentado en la sátira, la parodia y la ironía, que, en ocasiones, se asimila a (o conforma) auténticos "micropanfletos" que emplean muchas de las herramientas típicas del panfleto, incluyendo un amplio espectro de argumentos, no solo entimemáticos —como sostienen Slimovich (2018: 7), que se refiere a ellos como "píldoras de razonamiento", o Qués (2019: 47), para quien los tuits son "hilachas de discursos" - Incluso hallamos argumentos "no aristotélicos" o "pathémicos" (Angenot 2016: 88), como los preventivos ("lo que fue será"), la reducción al absurdo — caricaturesca-, la analogía y el razonamiento contrafáctico —aunado a la ironía一, los basados en tropos (como la metáfora), cuando no lo que se calificaría de "estallido emocional": tuits en los que no parece haber argumentación explícita, pero que, al construir discursivamente la repulsa al poderoso (u otra emoción similar), trazan una oposición.

\footnotetext{
3 La autora también se refiere al componente didáctico del DP en Twitter como "doctrina en grageas” (Qués 2019: 126).
} 
El objetivo de este trabajo es doble: por un lado, contribuir a la comprensión de cómo se produce la polémica tuitera a raíz de un "fin de ciclo" político y el comienzo de otro en México, y, por otro, esbozar una caracterización del tuit como "micropanfleto" o expresión ligada a la tradición del panfleto tradicional, contra los abordajes que estiman (desde Angenot 1982: 320-321) que se trata de un género en franca decadencia.

Los tuits analizados —extraídos de un corpus muy amplio- "se desencadenan" en al menos dos sentidos: en primer lugar, porque fueron suscitados por un hecho político de incuestionable relevancia para la sociedad mexicana, que alentó posturas enfrentadas (y, paradójicamente, no siempre explícitas), y, en segundo, porque el análisis debió extraerlos de la cadena aparentemente caótica, efímera e interminable en que se insertaban, formando, así, otra cadena: la polémico-argumentativa.

El orden de exposición será el siguiente: después de plantear algunas cuestiones relativas al corpus y la metodología, reflexionaremos sobre los rasgos del panfleto tradicional replicados en Twitter, para, finalmente, exponer algunos resultados del análisis discursivo del corpus desde el marco teórico-metodológico descrito.

\section{Corpus y metodología}

Los resultados que aquí exponemos proceden de un análisis discursivo de la dimensión polémica y de los rasgos del panfleto tradicional presentes en las respuestas de los internautas: 500 tuits a raíz de la "toma de protesta" del nuevo presidente mexicano, Andrés Manuel López Obrador (AMLO), y de la partida de Enrique Peña Nieto (EPN), extraídos de la cuenta de cada político.

Ambos se inscriben en marcos políticos diferentes. Por un lado, EPN, que llegó al poder de la mano del Partido Revolucionario Institucional (PRI), suele ser adscrito a una visión tecnocrática o neoliberal, y fue duramente cuestionado por múltiples causas de corrupción; por otro, AMLO, que integró las filas del Partido de la Revolución Democrática (PRD) y del PRI también, en sus orígenes, 
fundó el "Movimiento de Regeneración Nacional” (MORENA), que, como su nombre indica, propone el "fin de la política neoliberal"4, el combate de la corrupción y el fortalecimiento de "los valores culturales, morales, espirituales; no solo lograr el bienestar material, sino también el bienestar del alma”, como sostuvo al presentar la Cartilla moral de Alfonso Reyes ${ }^{5}$.

Los tuits analizados, filtrados por la red social misma como “más importantes” al 30/11/2018 (entre las 11:30 y 12:30 horas), fueron recolectados manualmente mediante capturas de pantallas, con el fin de mitigar su carácter efímero, inestable, ${ }^{6}$ y de garantizar cierta integridad ${ }^{7}$. Tras descartar los mensajes laudatorios, dado el objetivo de estudiar el componente polémico, el corpus se redujo finalmente a 221 tuits (136 de ellos contra EPN y 85 contra AMLO).

El análisis se apoyó en supuestos teóricos y metodológicos del Análisis del Discurso francés (Arnoux 2006, Charaudeau 2009, Charaudeau y Maingueneau 2005, Haidar 2004), articulados con conceptos relevantes de los estudios de la argumentación cotidiana (Gutiérrez y Plantin 2010, Plantin 2012) y de la polémica (Amossy 2011 y 2017), en su vinculación con el panfleto (Angenot 1982; Rojas 1997, 2003) y la historia de la prensa mexicana (Alonso 2003;

\footnotetext{
4 Declaraciones de AMLO en el cierre del Foro Nacional para la elaboración del Plan Nacional de Desarrollo 2019-2024. Véase <https://lopezobrador.org.mx/2019/03/17/ presidente-declara-inicio-de-un-cambio-de-regimen-en-el-pais-y-fin-de-la-politicaneoliberal/> [Consultado: 19 de marzo de 2019].

5 Texto encomendado en 1944 por la Secretaría de Educación Pública (SEP) a Alfonso Reyes, para incluirlo en la Cartilla alfabetizadora destinada a enseñarle a leer a una inmensa parte de la población. En enero de 2019, se cuestionó su inclusión al final de los libros de texto oficiales, por su supuesto conservadurismo y carácter religioso, en un Estado laico como el mexicano. Véase <https://www.elsoldemexico.com.mx/mexico/ sociedad/cartilla-moral-programas-sociales-secretaria-de-binestar-alfonso-reyesamlo-2917469.html> [Consultado: 02 de febrero de 2019].

6 Los tuits también presentan una "fragmentación conversacional", similar a la que Yus (2001: 62-63) detectó en los chats. En cierta medida, el hecho de que la plataforma misma filtre los tuits más importantes contribuye a no alterar (tanto) la riqueza del contexto, lo cual, como advierte Herring (2004: 11), es esencial al emprender un análisis de este tipo, "mediado por ordenador".

7 De acuerdo con las recomendaciones metodológicas de Cantamutto y Vela Delfa (2016), y de Ventura (2018).
} 
Gantús 2009; Rojas 1997, 2003 y 2010). Puesto que muchos de los tuits son productos semióticamente complejos ("postvisuales" o "visual-digitales" según Haidar 2019: 5), recurrimos también a herramientas de análisis de la argumentación visual ${ }^{8}$ desarrolladas por Groarke (2015, [1996] 2016) desde la Lógica Informal y la Pragmadialéctica, aunque tomando distancia de la cuestión de las falacias, pues, desde la argumentación cotidiana y en el marco de la revalorización de la polémica, los supuestos paralogismos pueden ser concebidos como eficaces mecanismos de argumentación.

Las sucesivas lecturas focalizaron en los mecanismos lingüísticos al servicio de la polémica, así como en otros tipos de respuestas que ponían en juego códigos semióticos diversos (memes, fotografías, gifs ${ }^{9}$, etc.), todos ellos orientados a plantear o reforzar el disenso. Si bien numerosos estudios indican que el discurso en línea es eminentemente subjetivo, individualista e incluso banal (Amossy 2017, Gallardo-Paúls 2017), hallamos ciertas "voces”, a partir de las cuales es posible reconstruir la figura de un adversario político (de EPN y de AMLO, respectivamente), que, con armas similares a las del panfletista de antaño, y sin importar la orientación ideológica, cristaliza una "identidad subjetiva colectiva" contestataria (Palti 2003: 178).

\section{El panfleto, ayer y hoy}

En la actualidad, "panfleto" y "panfletario" se usan para descalificar un escrito o un conjunto de ideas (Hastings 2009). "Libelo" o, en términos del escritor Silva-Herzog (2017), "papeles", "hojas sueltas" y "discursos de desecho", son solo algunos de los nombres con

\footnotetext{
8 Es decir, la argumentación que se produce mediante cualquier otro dispositivo semiótico ("no verbal”) que permita derivar una tesis o conclusión de determinadas premisas no lingüísticas.

9 De Graphics Interchange Formats (formato de intercambio de archivos) o animación sin sonido, más liviana que un video, que, aunque tiene ya varios años, se ha popularizado con las redes sociales (tanto que, en 2012, el Diccionario de Oxford eligió a gif como palabra del año). Además de transmitir con mayor nitidez una emoción, los gifs captan una mayor atención y resultan más virales. Véase https://rockcontent.com/es/blog/queson-los-gifs/ [Consulado: 19 de octubre de 2020]).
} 
connotaciones negativas aplicados a cualquier escrito "vehemente, incisivo, provocador, subversivo. Denuncia, condena, proscribe”.

Sin entrar, por el momento - pues ello demandaría un análisis más extenso-, en las diferencias implícitas en tales denominaciones, es importante recalcar que el carácter marginal, fugaz y fragmentario del panfleto tradicional, asociado al propósito de "tratar «asuntos del día», «de la actualidad» en un formato breve, pequeño y ágil” (Gómez Álvarez y Ozuna Castañeda 2015: 2), se emparienta con la naturaleza de los tuits, fuertemente apegados a lo cotidiano y, como aquellas hojas sueltas, con una tendencia a lo efímero, disperso, así como al humor, la ironía y la vehemencia.

Panfleto, debate público y polémica, a la vez, aparecen estrechamente vinculados en la bibliografía, aunque de modo algo difuso. Así, aunque los más recientes abordajes desde el Análisis del Discurso francés (por ejemplo, Amossy 2017, y los trabajos compilados por Montero 2016) han revalorizado la polémica como modalidad argumentativa, no siempre queda claro si el panfleto se asimila a la polémica, ni si necesariamente "moldea" un debate, como afirman, entre otros, Gómez Álvarez y Ozuna Castañeda (2015: 2). Siguiendo a Gutiérrez y Plantin (2010: 38), consideramos que el panfleto es una modalidad polémica más ${ }^{10}$ : "La polémica es un modo de comunicación social, un género retórico que puede ser el objeto de un estudio temático, reuniendo sátira, libelo, diatriba, panfleto, volante $[\ldots]$ ”, cuya argumentación pretende cristalizar el disenso. Y, como sabemos, lo natural en la discrepancia es que de ella "se parte", a diferencia del acuerdo, al que "se arriba” (Gutiérrez y Plantin 2010: 41), lo que explicaría la inconveniencia de abordar la escritura panfletaria desde nociones propias de una concepción de la argumentación "racional” y orientada al consenso.

Probablemente, lo distintivo del panfleto sea la violencia verbal, dado su interés por desacreditar y culpabilizar públicamente al oponente, mediante la puesta en evidencia, la "denuncia” (palabra clave) o el desenmascaramiento, muchas veces indignado (otra

10 Garand (2016) incluso lo considera una modalidad polémica "privilegiada”. 
palabra clave), de sus fallas y miserias (Hastings 2009: 35). No obstante, como veremos, la violencia es una cuestión de grado, y los internautas mexicanos parecen preferir otros modos más indirectos de manifestar discrepancia, como el humor polifónico y crítico, que emerge con voces y perspectivas heterogéneas, y que permite ridiculizar al oponente mediante recursos utilizados ya por la prensa del siglo XIX (Gantús 2009; Matallana 1999; Rojas 1997, 2003).

Le Bart (2009: 2) define al panfleto como ese discurso "doxológico y agónico" que se apega a una verdad unilateral, maniquea, y que así suele cristalizar un ethos o imagen de sí combativa, cuyas armas (orientadas al ataque) son la "franqueza brutal", el tono "afilado", insolente, la ironía y el insulto, además de la sátira y de la caricatura (Angenot 1982; Rojas 2003: 185).

Ese tono franco suele asociarse con "la prensa libre" y con la aparición de un sujeto marginal — su marginalidad se plasmaba en la escritura misma: rústica, descuidada, y la mayoría de las veces anónima-, quien fungía como "un político que solo participa del nivel informal de lo público, es decir, de la opinión" (Rojas 2010: 169), y que desde el papel podía enfrentarse a la élite económica y política: de ahí su descripción como "la maldición de las «clases peligrosas»" (Rojas 2010: 176). En este punto, nuestro corpus sugiere que el anonimato no parece determinante. En la actualidad, en la aparición de una escritura panfletaria ${ }^{11}$, por el contrario, lo que parece prioritario es la preeminencia de la subjetivación, "la posición evaluativa de un individuo sobre un estado de cosas" (Amossy 2017: 169), e incluso la falta de inhibición. El flaming es este fenómeno recurrente en la comunicación mediada por ordenador que se define como "un comportamiento verbal anárquico, liberado de toda inhibición, que tiende a emerger en los intercambios cara a cara electrónicos y que comprende injurias, insultos y un lenguaje blas-

\footnotetext{
11 Sin embargo, algunos estudios pragmalingüísticos han demostrado que el enmascaramiento tras un nickname alienta los estallidos de violencia que hacen trastabillar la cortesía verbal (Kaúl y Cordisco 2014) y facilita el enfrentamiento con un adversario ajeno a la vida offline del usuario "corriente" (Amossy 2017: 173).
} 
femo" (Amossy 2017: 165) ${ }^{12}$, el cual, por impertinente, provocativo y agresivo, es el acto de amenaza a la imagen por excelencia en el medio digital (Helfrich 2014: 298-299)

En el tuit, como en el panfleto tradicional, es posible reconstruir discursivamente dos polos antagonistas, que no necesariamente se manifiestan por vía de la violencia verbal, de las “injurias, los insultos y el lenguaje blasfemo”, retomando a Amossy. En línea con los trabajos históricos interesados por la circulación y recepción de las publicaciones populares (Gantús 2009; Gómez Álvarez y Ozuna Castañeda 2015; Matallana 1999; Rojas 1997, 2003), la escritura panfletaria podría ser definida como una forma "simbólica de interpretación y de construcción de la realidad” (adoptando la definición de caricatura política que emplea Gantús 2009: 14), una realidad plagada de desacuerdos con diverso grado de hostilidad.

La polarización social resulta particularmente evidente en las redes sociales, en las que se ha detectado una "dimensión argumentativa” (Amossy y Burger 2011; Mazzuchino 2018, 2019; Salerno 2018), producto de la dinámica interactiva de los mensajes en forma de cadenas de discusión. De ahí la presencia de unas intervenciones que, aunque puedan parecer desvinculadas unas de otras (pues los internautas no siempre interactúan de modo explícito, "cara a cara”, ni debaten en sentido estricto, y a veces ni siquiera "se responden"), van construyendo "bandos" en pugna o "comunidades de protesta" (concepto de Amossy y Burguer 2011: 4, sobre lo observado en los foros de Internet).

Por ello, aun los tuits aparentemente incoherentes o desvinculados del tuit original, pueden catalogarse como respuesta o reacción, e incluso ser considerados argumentativos ${ }^{13}$, debido a que, como ya señalaron trabajos previos en torno del insulto en otros géneros y medios (Amossy 2016: 29 y 2017: 61; Cediel y Olave

\footnotetext{
12 En esa misma página, Amossy resume otras investigaciones que rechazan que el flaming sea exclusivo del ciberespacio.

13 Esto desde la perspectiva de la argumentación cotidiana; para otros, como Pardo y Noblía (2015), en cambio, los comentarios no son "Ni diálogo ni debate", y la violencia típica de las redes es "un problema social” ligado a la "catarsis” (2015: 119-120).
} 
2018), se valen de recursos vinculados con la construcción de un ethos peculiar, a través del cual se busca argumentar en el sentido de fijar una posición y de cerrar filas en torno de ella, y no de desplegar argumentos orientados a la persuasión ${ }^{14}$.

No estaríamos, pues, ante formas argumentativas desvirtuadas o desviadas, sino ante un tipo peculiar de argumentación, que oscila entre la polémica y la tradición de la vituperación y la erística (Olave 2019, Schopenhauer [1830] 1997), y que, en términos de Genette ([1972] 1989: 10), podemos considerar intertextuales, en la medida en que reactualizan el comentario (metatextualidad) o impulsan la imitación (hipertextualidad), entre otras posibilidades, como el "pastiche satírico", es decir, "la deformación lúdica, la transposición burlesca de un texto o la imitación satírica de un estilo, que tienen como elemento común el efecto cómico" (González Doreste 1993: 86). En un trabajo anterior (Mazzuchino 2018) hemos advertido una orientación satírica y paródica en los tuits políticos, ligada a un humor polifónico y carnavalesco, en sintonía con lo que Amossy (2017) identificó también en los foros en línea; aquí mostraremos, además, cómo esa expresión paródica de ridiculización-desmitificación del poderoso puede leerse en clave panfletaria.

Al igual que en el panfleto mexicano de comienzos del siglo XIX, en los tuits polémicos se detectan posturas divergentes, así como una marginalidad, entendida, por un lado, como representación de las experiencias sociales de los marginados y, por otro, como escritura antinormativa (con faltas ortográficas, ausencia de signos de puntuación e imitación de la oralidad), la cual "articula la jerga vulgar a través del uso de giros grotescos, frases obscenas [...] refranes y jerigonzas [...] el uso reiterado del diálogo y la vuelta a las tradiciones orales de la burla y del carnaval" (Rojas 1997: 45-46), y en la cual resuenan fábulas, parodias y diálogos de la literatura

\footnotetext{
14 Qués (2019: 123) también reconoce “un ethos panfletario que encuentra en Twitter un ecosistema favorable", pero no ahonda en las similitudes concretas entre el tuit y el panfleto.
} 
picaresca y de cordel, todo lo cual "denota una resistencia a la institucionalidad de la escritura” (Rojas 2010: 178-179).

Por supuesto, lo anterior no implica asumir que los tuiteros, como muchos panfletistas de otro tiempo, tengan escasos estu$\operatorname{dios}^{15}$; sabido es que la lengua de Internet es híbrida, a medio camino entre la oralidad y la escritura ${ }^{16}$, y que los usuarios suelen cometer transgresiones voluntarias a la norma con objetivos humorísticos, irónicos o paródicos, cuando no de identidad o pertenencia grupal (Carvajal Barrios 2017: 210; Mancera Rueda y Pano Alamán 2013a).

En ese sentido, la repetición de groserías panfleto tras panfleto puede responder a la necesidad de establecer o reforzar la complicidad con el destinatario ${ }^{17}$, pero también puede entenderse como un medio de construcción del arquetipo y aun caricatura del panfletista como sujeto marginal (Rojas 2010: 179). Asimismo, la viralización de contenidos — muchos de ellos, escatológicos y violentos- en Twitter no solo hace más próximos a quienes comparten esos contenidos, sino que también expresa la huella de identidad de su grupo: "comunidad de protesta" o "círculo" (palabra clave al hablar del panfleto, el cual involucraba a un "núcleo a partir del cual se desplegaban estrategias políticas” y se ponía de manifiesto una “interacción agonal” (Palti 2003: 175-178).

Los panfletos eran "voceados" en las calles y distribuidos en lugares populares -en México, en los suburbios, en las fondas, en las pulquerías, en los cafés, en los portales, e incluso a la salida de la Cámara de Senadores y de Diputados (Rojas 2010: 182-183)—; de la misma forma, los tuits parecen moverse de un lado al otro: “circulan" por el espacio informe de la red. Standage (2013) señala curiosos paralelismos entre las redes sociales actuales y las que se establecieron antaño en Europa, cuyo núcleo privilegiado fue el café, lugar de socialización y de discusión abierta a cualquiera,

15 Standage (2013) recuerda a panfletistas cultos, eximios novelistas, como Jonathan Swift o Daniel Defoe.

16 Al punto de que se han ideado otros mecanismos para suplantar a lo no lingüístico y paralingüístico, como los emojis y emoticones.

17 Helfrich (2014: 315) incluso advierte un uso del flaming con fines de entretenimiento. 
donde también se escribían y ponían en circulación los panfletos, de ahí que el autor llegue a calificar a Twitter con el término de "global coffehouse" 18 .

Podríamos, no obstante, mencionar al menos dos aspectos inherentes al panfleto mexicano de antaño que, al parecer, no se conservan en los tuits actuales (o que no hemos apreciado en nuestro corpus). Por un lado, los tuiteros-panfletistas pueden no llevar una "vida vagabunda, pobre e insalubre" (Rojas 1997: 52), e incluso los hay mujeres (los autores coinciden en que era oficio de hombres); por otro, aunque el ethos desplegado es el de la sinceridad brutal (el "hablar sin pelos en la lengua"), la invectiva no constituye hoy una auténtica parresia que ponga en riesgo la vida (Foucault 2017: $58)^{19}$, sino que aparece como una "matriz original de diferentes experiencias" en torno de la crítica pública (Hastings 2009: 38) y del hablar sin pudor, espontáneo e incluso inmoderado, lo que aquí vinculamos con el flaming típico de las redes sociales. En los tuits tampoco hay siempre un decir "directo", "transparente" (Foucault 2017: 48), porque se prefieren la máscara de la ironía y otros modos de expresión indirectos, incluido el humor. En todo caso, hay un "pacto" aparentemente parresiástico (Foucault 2017: 34-35), que consiste en que el más fuerte deje al más débil un espacio abierto para decir una verdad "que puede herirlo a él, el amo", sin que ello implique erigirlo en consejero o maestro ni, mucho menos, meditar sobre sus dichos (o siquiera leerlos). Los tuits tienen de parresiástico cierto tono aparentemente sincero ${ }^{20}$, contrapuesto al que emplearía

\footnotetext{
$18 \mathrm{Al}$ igual que las redes sociales actuales, sobre los cafés ingleses del siglo XVII pesaba la acusación de que distraían al pueblo de sus obligaciones, especialmente a los jóvenes, y de que propiciaban discusiones triviales, ligadas al entretenimiento y poco "intelectuales" Frente a esta visión, que perdura en la actualidad, Standage (2013) recalca que los cafés eran lugares intelectualmente estimulantes. Le agradezco mucho a uno de los evaluadores el haberme acercado a esta obra.

19 Cuestión que advirtieron ya Cediel y Olave (2018: 100), al analizar "la dimensión política del insulto” en el discurso de la guerrilla colombiana, cuando señalan que la parresia está limitada, en todo caso, a la "construcción discursiva”, retórica, de un ethos indignado, desinhibido e irrespetuoso.

20 Foucault (2017: 150) después distingue entre sinceridad/parresia y athyrostomia, la “versión negativa” de aquella, que implica un decir "sin filtro" e indiscreto, pero franco.
} 
un adulador, pero no hay que perder de vista que la relación entre los interlocutores, si bien asimétrica - como en el concepto original (Foucault 2017: 35)—, no es de amistad ni de consejo, sino de enfrentamiento y discrepancia.

En ese marco, aunque se ha insistido en que la polémica garantiza ser escuchado y evidencia el combate entre dos posturas, con lo cual se reconoce al oponente y se evita que se rompa el vínculo social (Garand 1998, citado por Amossy 2011: 26), nos interesa analizar cómo ciertas estrategias permiten enfrentar y combatir el statu $q u o$, al menos desde el lenguaje y por medio del humor, cuestión en la que nos centraremos a continuación.

\section{Análisis discursivo}

4.1. El punto de partida: los tuits presidenciales

Nuestro corpus surge como reacción más o menos virulenta a ciertos tuits de AMLO y de EPN, que materializan diferentes visiones acerca de la política:

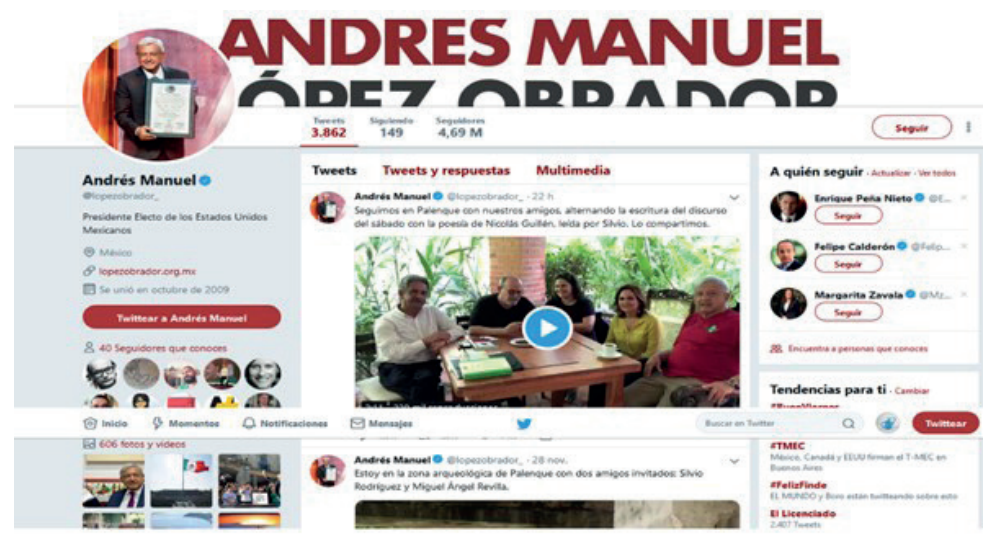

Deberemos ahondar en ello, porque este concepto parece más próximo a lo que evidencian los tuits. 
(2)

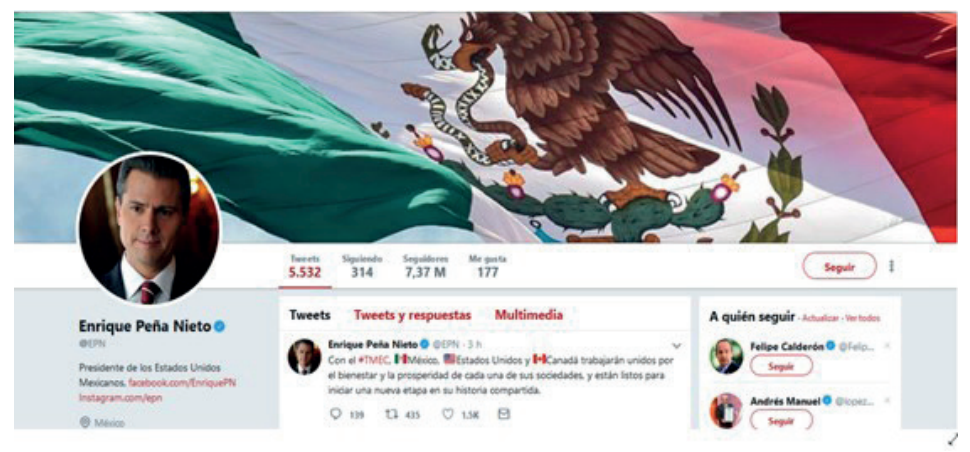

La cuenta de Twitter de AMLO (1) destaca su nombre, al fondo, en letras de molde; su foto de perfil lo muestra sonriente, sosteniendo el diploma de presidente electo (otorgado por el Tribunal Electoral, el cual validó su elección). Debajo, como descripción, se lee lo siguiente: "Presidente electo de los Estados Unidos Mexicanos" (la asunción aún no se había concretado) ${ }^{21}$.

En la cuenta de EPN, en cambio, de fondo aparece la bandera mexicana (con foco en el águila devorando la serpiente, lo que dispara connotaciones de carácter aguerrido); su descripción es muy escueta: "Presidente de los Estados Unidos Mexicanos", e incluye el enlace a otras redes sociales: Facebook e Instagram, lo que lo presenta como un líder moderno y en contacto con sus seguidores a través de las redes sociales.

En la imagen (4), EPN aparece junto con Trump y Trudeau, en ocasión del G20 en Argentina, firmando el nuevo tratado comercial de México, Estados Unidos y Canadá (TMEC). En sus últimos tuits como presidente, recalca la relevancia del TMEC para México, en un estilo formulario, impersonal y despojado de emoción, que incluso recuerda al de las diapositivas de Power Point empresariales (ver la imagen 3), con su aparente orientación explicativa y la inclusión de viñetas (extrañas en un tuit, cuyo texto es continuo).

21 Hoy (19/11/2019, a las 15:00 horas), AMLO se define como "Presidente Constitucional de los Estados Unidos Mexicanos”, mientras que EPN también ha cambiado su descripción biográfica a "Presidente de México 2012-2018". Su último tuit, del 18/06/2019, busca “rechazar categóricamente las falsas acusaciones en su contra”. 
El recurso de la metonimia ("México, Estados Unidos y Canadá trabajarán unidos por el bienestar y la prosperidad de cada una de sus sociedades, y están listos para iniciar una nueva etapa en su historia compartida") contribuye a presentarlo como un presidente que habla en nombre de su país (y del de los otros dos "socios" del polémico tratado), cuya iniciativa (la firma del tratado) implica un nuevo inicio y una proyección histórica para todos. México aparece a la par de sus "socios", en igualdad de condiciones y no sojuzgado por ellos, lo que podría leerse como una reacción a las innumerables críticas contra el pacto. El entonces casi expresidente se dice "muy honrado de haber participado en la firma del nuevo Tratado Comercial”, que parece condensar su gobierno entero.

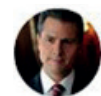

Enrique Peña Nieto @EPN·30 nov. 2018

El \#TMEC es el primer tratado comercial con elementos para atender el impacto social del comercio internacional:

$\checkmark$ Facilita la participación de más sectores de la economía; $\checkmark$ Amplía la protección de derechos de los trabajadores; y $\checkmark$ Fortalece el cuidado del medio ambiente.

() 388

$\uparrow 1,1 \mathrm{mil}$

O $5,3 \mathrm{mil}$

个

(4) Enrique Peña Nieto @EPN·30 nov. 2018

En mi último día como Presidente, me siento muy honrado de haber participado en la firma del nuevo Tratado Comercial entre México, Estados Unidos y Canadá. Este día concluye un largo proceso de diálogo y negociación que consolidará la integración económica de América del Norte.

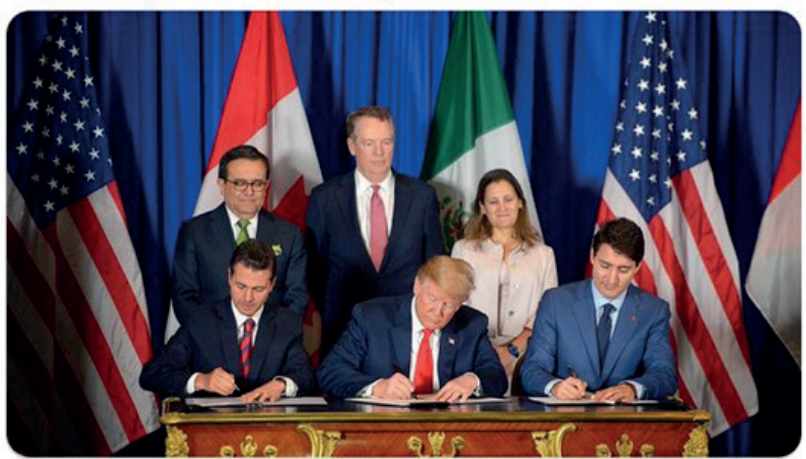


La fotografía del tuit (4) muestra a un EPN reconcentrado en la acción simultánea de firmar el acuerdo con sus pares, en una situación extremadamente formal (en un ambiente cerrado y algo oscuro, en cuyo fondo hay un telón y banderas, lo que acrecienta la impresión de estar frente a una representación teatral; los papeles, sobre una mesa estilo Luis XVI, contribuyen también a dibujar una frontera entre el presidente y la gente "común"). La foto fija el momento más protocolar, pues, como sabemos, EPN cometió varias "peñadas"22; por ejemplo, al momento de firmar el tratado, que fueron objeto de burla en los medios y en las redes sociales.

En contraste con esta imagen protocolar, en el tuit (1), AMLO aparece departiendo plácidamente junto al cantautor cubano Silvio Rodríguez y otros "amigos", los rostros sonrientes y los cuerpos relajados. Del tuit emerge un enunciador plural, que interpela al lector. El presidente electo se presenta ante una mesa rústica, corriente, en un ambiente íntimo (en su propio rancho de Palenque), rodeado de vegetación y de luz solar. El contraste con EPN (encierro, penumbras, seriedad, ensimismamiento) es notable. "Silvio", como llama con afecto al cubano, lo ayuda a escribir su discurso, mientras leen la poesía de Nicolás Guillén.

El poema de Guillén, publicado un año antes de la Revolución Cubana e inscrito en el movimiento de la conformación de una nueva identidad mestiza y revolucionaria (Balbuena 2014), está estructurado en frases cortas y simples, que remedan un monólogo interior. El texto establece oposiciones y paralelismos entre lo que hay que dejar entrar en la muralla y lo que hay que rechazar: "Alcemos una muralla/juntando todas las manos/los negros, sus manos negras/ los blancos, sus blancas manos". La metáfora de la muralla es muy significativa: actúa "como elemento fuerte y sólido que [...] [resguarda] el interior de algo; en este caso, el de la nueva nación. Pero también [es la] muralla como aislante, cerco, muro inmenso e indestructible que aleje todo lo negativo que quiera entrometerse en la nueva nación cubana" (Balbuena 2014).

\footnotetext{
22 Palabra que tomamos de uno de los tuits, y que se refiere a sus frecuentes exabruptos y “deslices”.
} 
En vísperas de la toma de protesta presidencial ${ }^{23}$, la imagen de la muralla se resignifica, pues AMLO parece hacer una invitación al pueblo de buena fe a juntar las manos en un proyecto común, el suyo, y a "hacer frente común" para rechazar a los opositores.

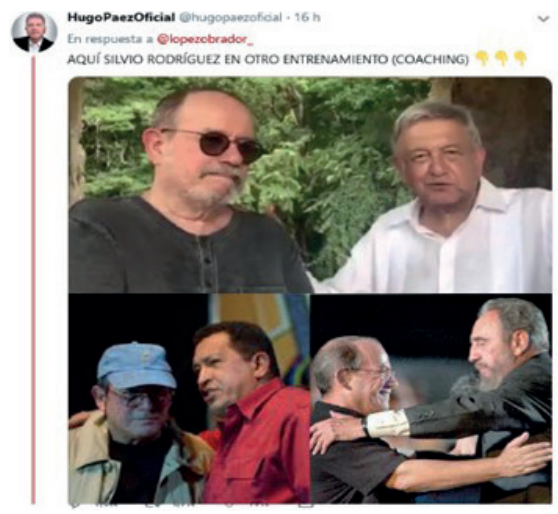

La imagen que acompaña al tuit (5) refuerza la idea de que lo que Silvio Rodríguez está haciendo es "otro entrenamiento (coaching)", lo que matiza el tipo de ayuda que está recibiendo AMLO y la conecta con una tradición: la de la revolución latinoamericana (“entrenamiento" adopta matices militares, por el diálogo con las fotos de dos líderes revolucionarios: Chávez y Fidel Castro). Rodríguez aparece en actitud de escucha ante ellos, como consejero, y esto crea la impresión de que el pueblo (y sus emociones, que aquel trasmite con su música) están presentes en este momento previo a otro crucial: la llegada al poder de la izquierda mexicana ${ }^{24}$.

23 La Constitución Política de los Estados Unidos Mexicanos dispone, en su artículo 128, que "Todo funcionario público, sin excepción alguna, antes de tomar posesión de su encargo, prestará la protesta de guardar la Constitución y las leyes que de ella emanen”. Por medio de este acto previo al ejercicio de su cargo, frente a los legisladores (diputados y senadores), en representación del pueblo, el funcionario se compromete individualmente a "fundar y razonar todos sus actos en la Ley, preservando con ello la legalidad y el Estado de Derecho”. Véase el Sistema de Información Legislativa de México: < http://sil.gobernacion.gob.mx/Glosario/definicionpop.php?ID=197> [Consultado: 01 de junio de 2020].

${ }^{24}$ No debatiremos aquí sobre si es o no una izquierda "auténtica”. 
Si consideramos que "la fotografía se presta mucho mejor que el cine para elaborar el duelo, porque nos permite recordar a los muertos en tanto muertos, sin las marcas del estar vivos" (Metz 1985, parafraseado por Carlón 2016: 34), el instante fijado en las fotos de AMLO lo vincula emotivamente con una tradición revolucionaria cuyos líderes, aunque muertos, siguen vivos. Por el contrario, la imagen que EPN contribuye a perpetuar (junto a cuestionables "amigos" de México, en especial Trump), podría leerse como un modo de duelo, pues, entre los internautas, si bien hay felicitaciones, lo que sobresale es la alegría por la "partida" del político, así como su conceptualización como "muerto en vida" o desterrado de la vida en sociedad.

EPN parece insistir, aun visualmente, en proyectar el ethos de estadista, y no el de hombre común, en situaciones privadas (que supo hacer públicas en otras ocasiones, al igual que otros políticos de la actualidad, tal como lo mencionan Carlón 2016 y Slimovich 2018). El uso de la fotografía puede responder también al deseo de fijar una imagen seria de un presidente que, como veremos, con sus numerosos lapsus linguae o torpezas, motivó risas (y lo continuó haciendo en su última aparición pública durante el G-20).

AMLO, en cambio, escoge hablar a la cámara en un entorno natural y relajado, en el fluir de un momento, el de una reunión con amigos íntimos que se inscriben (por sus trayectorias vitales) en una corriente antiimperialista y latinoamericanista.

\subsection{El tuit como micropanfleto: las voces discordantes}

Derivada de los tuits iniciales de los políticos —expuestos en la sección anterior-, se puede reconstruir una extensa cadena reactiva (un hilo de tuits) en la que, como en el panfleto de antaño, resuenan voces de resistencia $a^{25}$. Pese a que, estrictamente, no se observa un diálogo al modo de los intercambios orales - menos aún entre los internautas y los políticos (Mancera Rueda y Pano Alamán 2013b)—, sino que cada internauta puede aparecer en el momento que desee

\footnotetext{
25 También en Inglaterra, este era un rasgo distintivo del panfleto: el erigirse en punto de resistencia al statuo quo, como apunta Standage (2013).
} 
para comentar lo que le plazca (se interpreta en relación con el tema de interés, como ocurre en cualquier comunicación), no estamos siempre frente a un "diálogo de sordos" (Angenot 2016), dado que en Twitter hay otros modos de interacción más allá del lingüístico, como el fav o el retuit, en los cuales este trabajo no se detendrá.

Pese a su aparente singularidad y fragmentación, usamos indistintamente "tuit" y “comentario" porque, en líneas generales, las respuestas reactualizan el comentario tradicional puesto que estas constituyen un "despliegue metatextual que remite de diversas maneras al texto-objeto" (Arnoux y Blanco 2007: 64) y que se orienta a "decir por fin lo que estaba articulado silenciosamente allá lejos” (Foucault 1973: 23), en la fuente ${ }^{26}$. Esta remisión al texto primero no debe sobrepasar el límite de interpretación impuesto por aquel, lo que, desde Fuchs (1994), se conoce como el "umbral de distorsión” permitido. En Twitter, el comentario involucra operaciones y recursos no exclusivamente lingüísticos, que deberemos estudiar mejoren el futuro.

\subsubsection{Contra EPN}

EPN es blanco de un mayor número de ataques ${ }^{27}$, lo que puede explicarse por el hecho de que sus tuits, que se pretenden laudatorios (al condensar su gestión en lo que se expone como su mayor logro), se enmarcan en el fin de un sexenio plagado de denuncias, tanto por cómo ascendió al poder (tras acusaciones de fraude

\footnotetext{
26 La equiparación entre tuit y comentario se condice con la clasificación de los géneros breves propios del discurso digital propuesta por Cantamutto y Vela Delfa (2020: 14), quienes distinguen entre publicación/comentario ("unidades de orientación interactiva complementaria: iniciativa y reactiva”, por lo normal, de carácter público), y mensaje ("más orientado hacia lo interpersonal y conversacional”, además de privado). Deteniéndose en el comentario digital de noticias periodísticas, Sal Paz (2016) también define al comentario como género breve "interactivo prototípico del ciberespacio, que se distingue, fundamentalmente, por su carácter multidireccional, abierto, colaborativo y participativo", que contrasta con otros géneros interactivos de la prensa, como la carta de lector, cuya argumentación es "más cuidada y meditada".

27 En el momento de la conformación del corpus (el 30/11/2018, entre las 11:00 y las 12:30 horas), él estaba recibiendo un mayor volumen de tuits críticos, situación que pudo haber cambiado hoy, a dos años del gobierno de AMLO.
} 
electoral, contra AMLO, nada más ni nada menos), apadrinado por el expresidente Carlos Salinas de Gortari y bajo los auspicios del multimedio Televisa ${ }^{28}$, como por el incremento de la violencia, la desaparición forzada de miles de personas —entre ellas, la de los 43 jóvenes de Ayotzinapa ${ }^{29}$ - la caída de la economía y la crisis con EUA. Asimismo, también se vio involucrado en diversas causas de corrupción ${ }^{30}$.

De los innumerables tuits adversos que "responden” a los de EPN, nos centraremos en los que presentan rasgos propios de la polémica digital próximos a la escritura panfletaria. En ellos, lo sobresaliente es la construcción, entre los “seguidores”, de una voz humorística que tiende a la caricaturización ${ }^{31}$, mediante diversas estrategias que gravitan en torno de la argumentación ad hominem, de quien pretende ofrecer una imagen seria y profesional de sí mismo y de su gestión. Esta corriente satírico-burlesca, por momentos violenta, se canaliza mediante videos que recuerdan las "peñadas": desde la mala pronunciación del inglés y los gestos de torpeza de EPN durante la cumbre del G-20 en Argentina o, antes, al saludar a Obama y Trudeau, hasta un gesto durante la última ceremonia de "El grito" 32 que pretendió representar al corazón (el popular gesto del amor), pero que fue interpretado de modo humorístico y

\footnotetext{
28 Recordemos que se casó con la actriz de telenovelas Angélica Rivera, conocida como la Gaviota (por el personaje que la hizo famosa), en la "boda del momento” que simbólicamente unió farándula y política.

29 El relato oficial que transmitió la Procuraduría General de la República consideró el hecho como un "asesinato masivo" en manos del narco, en connivencia con la policía y el poder político.

30 La más escandalosa de las cuales, tal vez, fue la conocida como la "Casa blanca”, por la propiedad de USD 7 millones donde vivía con Angélica Rivera, y que supuestamente ella le compró al Grupo Higa, encargado de obras millonarias en el Estado de México durante el gobierno de EPN.

31 Toda forma satírica, verbal o visual que, a diferencia del retrato, se asienta en la comparación cómica y en la interpretación (y el cuestionamiento) de una realidad (Gantús 2009). Para Claudín y Arabitarte (1986), citado por Matallana (1999: 22), es un “dibujo que resalta ciertos rasgos o características de un personaje, una cosa o un hecho, apoyándose generalmente en el humor o la crítica.

32 Celebración así conocida por el grito del cura Miguel Hidalgo, al inicio de la Independencia (el 16/09/1810), cuando arengó a los mexicanos a levantarse en armas contra España.
} 
aun escatológico, como la imitación del famoso gesto de un personaje de manga, o como un ano, entre otras posibilidades ${ }^{33}$ :

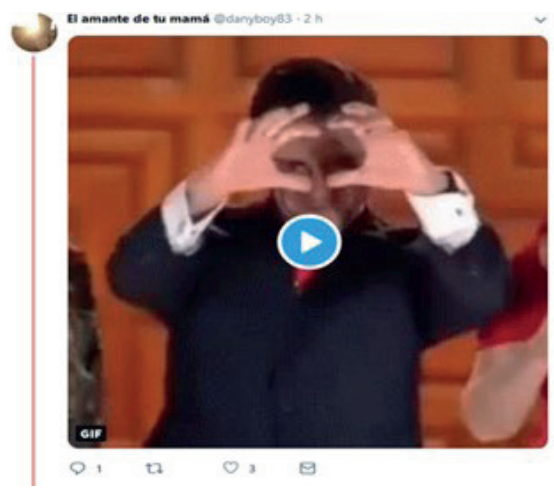

De tuits como los anteriores emerge una voz que podríamos llamar la "guasa popular", que contrasta fuertemente con la voz del político, pues anula toda distancia respetuosa e ignora el protocolo, al hablarle "de tú a tú" con el fin de degradar su (pretendida) imagen prestigiosa para, en última instancia, exhibir su impostura, un aspecto observado en el panfleto tradicional (Angenot 1982: 260). Esta voz manifiesta la falta de respeto típica del panfleto (Fanduzzi 2008), que se traduce en el uso de fórmulas de confianza y de términos corrientes en el habla coloquial y aun vulgar (como wey, beibi ${ }^{34}$ ), con los que se acentúa la estolidez de EPN, así como su naturaleza corrupta, como queda patente cuando lo equiparan, mediante un gif, con el estafador Jordan Belford (personaje interpretado por Leonardo DiCaprio en El lobo de Wall Street), lo que refuerza la imagen falsa y "vendida" a las potencias del mandatario.

En reemplazo de la foto oficial y de la imagen acartonada que EPN pretende imponer, hay quien propone otra efigie para él,

33 Los periódicos dieron cuenta de la burla de la que fue objeto el presidente con ese gesto "raro, magullado" (entre muchos otros. Véase <https://www.sinembargo.mx/1609-2018/3472112> [Consultado: 17 de septiembre de 2018]).

34 Güey o buey: palabra en su origen ofensiva, que se aplica a quien se estima tonto o despreciable (Diccionario del Español de México/DEM, COLMEX, en línea: <www.dem. colmex.mx $>$ ). En la actualidad, también es un coloquialismo que circula entre los jóvenes. 
la de un burro, animal tradicionalmente asociado con la torpeza, la necedad y la ignorancia, que, según Gantús (2009: 286), en la caricatura política mexicana representaba, además, la impostura:
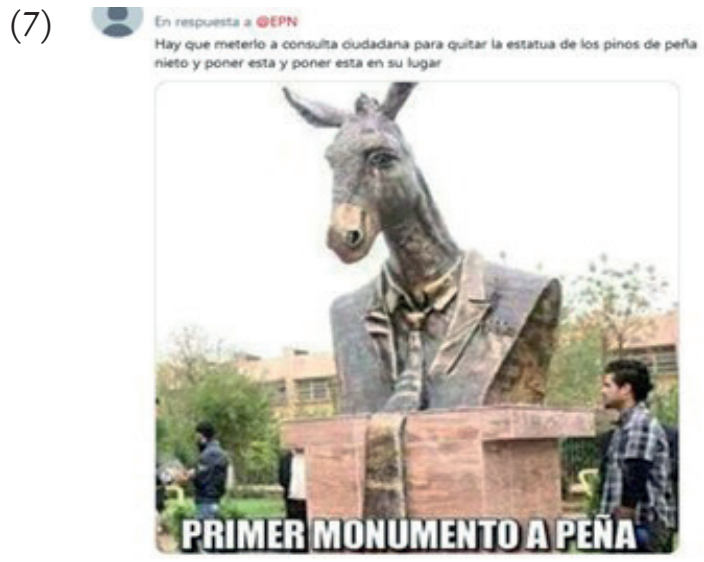

En Los Pinos, hasta fines de 2018, la residencia oficial de la familia presidencial y hoy centro cultural abierto a la población, hay un paseo con las efigies de todos los presidentes; el meme (que integra lo visual con lo lingüístico) se mofa de (y deconstruye) la imagen oficial de EPN y propone otra, alternativa, ridícula ${ }^{35}$ y ligada a lo popular. Estamos ante una sátira más visual que lingüística, que, en un mínimo espacio y con mínimos recursos, pero muy potentes, forja una imagen semióticamente compleja y ridícula de EPN (un "arquetipo", según Goudet, 2016), que, como la caricatura de antaño, obedece al "escarnecimiento de la autoridad, la ridiculización de la persona aludida, la desacralización de la política" (Gantús 2009: 391).

\footnotetext{
35 El propósito fundamental de estos dispositivos “ícono-textuales” (Goudet 2016) Esta referencia no se encuentra consignada en la bibliografía. En ello coincide Jost (2019), quien ha señalado la dificultad para establecer la frontera entre lo lúdico y satírico. El semiólogo propone una clasificación de los memes en lúdicos, críticos o serios, según su función paródica, crítica o de transmisión de fakes news, respectivamente. Para Scolari (2019), el meme "retoma tradiciones de la publicidad y el arte, juegos de imágenes y palabras [...] Es una especie en permanente mutación”, algo que demuestra también (Yus 2018).
} 
Otro recurso polemizador típico en el corpus es el hashtag (\#), cuya función excede la de etiquetar u organizar contenidos, para convertirse en condensador argumentativo - "palabra-argumento" según Husson (2016: 106), siguiendo a Paveau (2013)—, una especie de lema que sintetiza y abre, a la par que promociona o "vocea", la tesis o conclusión propuesta, de modo similar a como lo hacía el panfletista de antaño, en la calle, pero en la nueva "vía pública", que es la red. En este caso, \#SexenioParaelOlvido, en oposición al “éxito" que pregona el tuit presidencial, así como el motivo o "evidencia” de la desaprobación y, en definitiva, del fracaso de EPN:

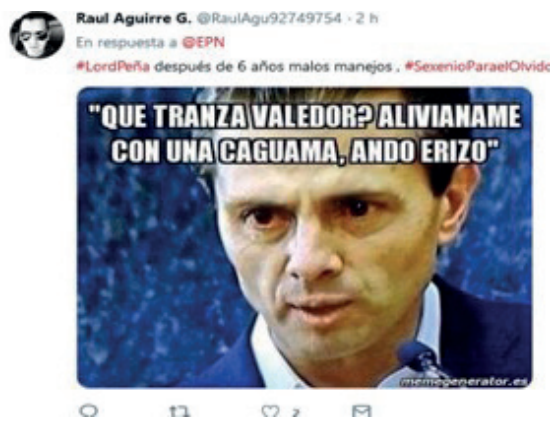

Otra etiqueta crítica de EPN que encontramos dentro del corpus lo identifica como prototipo de una clase a la que, evidentemente, no pertenece el internauta: \#LordPeña. Con los descalificadores "lord" y "mirrey", se designa a los jóvenes de clase alta, inescrupulosos, clasistas y altaneros que desprecian al pueblo, y EPN es presentado como uno de ellos, al menos en el mensaje lingüístico, pues en el meme él habla (en estilo directo) como alguien del pueblo que reclama una cerveza grande (“caguama”) porque está ansioso por abstinencia de alcohol (“andar bien erizo”). La deformación fisonómica (ojos grandes y enrojecidos, tez pálida, boca babeante) se condice con una deformación del habla, la sermocinatio, sermocinación o discurso directo ficticio, típicamente panfletario (Angenot 1982: 289; Bonnafous 2016: 92).

El meme subvierte el orden "normal”, al atribuirle al presidente una idiosincrasia y un sociolecto que no parecen propios de él o que 
no coinciden con la imagen mediática instalada; hay una especie de antítesis entre el texto y la imagen, porque el "lord" habla como si no lo fuera: "Se produce un efecto de subversión dialógica: la imagen prestigiosa tomada al adversario es degradada por el polemista, que la sustituye por un análogo irrisorio" (Angenot 1982: 261). El humor se basa en ese contraste, pero también genera la interpretación crítica de que EPN sufrirá otro tipo de abstinencia, la derivada de no poder beber más "las mieles" del poder.

La polémica, en su vertiente popular-festiva, toma elementos de múltiples fuentes audiovisuales, incluso de las telenovelas o productos de Televisa — que, paradójicamente, fue el multimedio que promocionó a EPN-, como el programa infantil El chavo del ocho (imagen 9). Aparecen, así, referentes entrañables para muchos, pero también cuestionables en tanto productos enlatados que ofrecen una mirada estereotipada del pueblo, de la mujer y de las relaciones humanas:

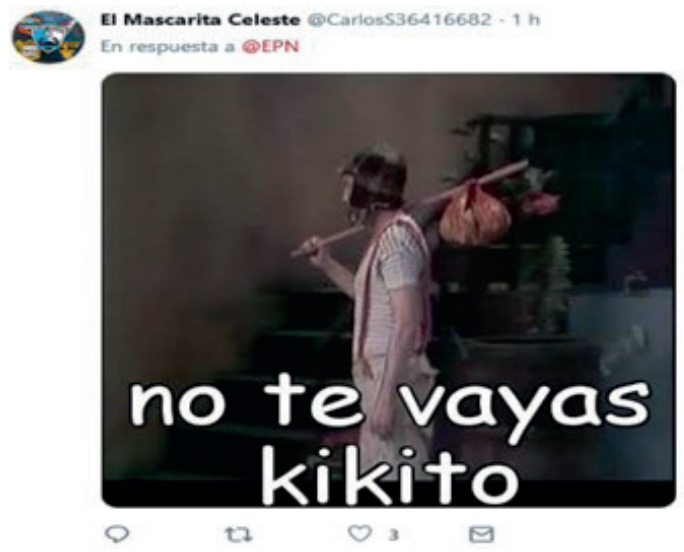

En esta cadena de tuits se construye una imagen infantilizada del político, que contrasta con la versión oficial, ya que el Chavo (renombrado como "Kikito", diminutivo de "Enrique") es un adulto-niño que se va con sus petates a cuestas. El presidente también es comparado con Woody, el protagonista de la película de animación Toy Story, lo cual conecta su imagen con la de un muñeco, e instaura la lectura política de que es un "pelele", lo que 
acentúa su ridiculez y fragilidad, en el marco del tratado con los poderosos, los “grandes" o adultos de Norteamérica. Este tipo de caricatura política tampoco es nueva: se sabe que así se representaba al dictador Porfirio Díaz (Gantús 2009: 190), con quien se conecta a los opositores ("neoporfiristas") de AMLO.

La caricaturización de la figura presidencial también se despliega junto con la parodia del lenguaje religioso y falsamente respetuoso de las jerarquías:

\section{3. yeyislpz @6754697df8d24dd . $53 \mathrm{~min}$ \\ En respuesta a @EPN}

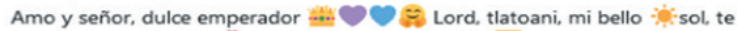
vamos a extrañar bb $\rightarrow$ no te olvides de tu pueblo $\boldsymbol{\Omega}$.

Q $\tau]^{1} \quad \mathrm{llll}_{3} \quad \forall$

“Tlatoani” era el título de Moctezuma, el jefe azteca que de modo voluntario rindió vasallaje ante Carlos I de España, con lo cual implícitamente se retoma la argumentación de que EPN está claudicando ante el extranjero. Esta visión pasiva del político contrasta con la que se instaura en tuits como (11), que focalizan en su capacidad destructora, al equipararlo con Terminator ${ }^{36}$ (un "nohumano). Otros tuits, como (12), retoman esta línea argumentativa:
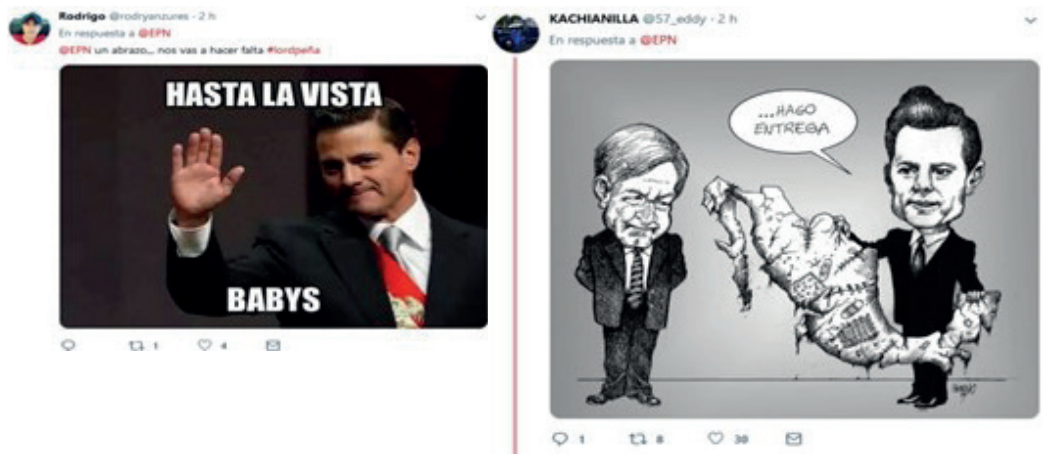

36 Personaje de la película homónima de James Cameron (la primera película de la saga es de 1984), que es un ciborg asesino enviado desde el futuro. 
Ante la mirada reprobatoria de AMLO, en la imagen (12), lo que EPN entrega son los despojos del país; lo entregado no aparece nombrado, sino que se expone visualmente como harapos.

La veta humorística y polémica también surge de los supuestos agradecimientos y de los mensajes aparentemente solícitos (13), que, en el hilo de tuits, no fungen como meras interpelaciones, sino como verdaderos actos de denuncia:

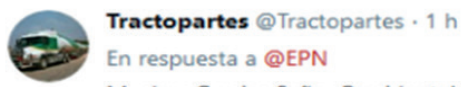

Muchas Gracias Señor Presidente! Enhorabuena! Pocos líderes como Usted lo entregan todo y hasta el último día de su Gobierno! Gracias por todo! Le deseo lo mejor en sus actividades futuras! YIF. T.•.A.•.F.•.

En (13), la ambigüedad de "entregarlo todo", que en una primera lectura puede leerse como el desinterés atribuido al servidor público, en realidad propicia otra lectura, sostenida por las abreviaturas finales. Las "actividades futuras" de EPN tienen que ver con los placeres carnales (hay continuas referencias a su belleza y sus apetitos sexuales), y, humorísticamente, con la subcultura Furry Fandom: intercambio sexual entre animales antropomórficos (propios del fanzine y la ciencia ficción). En vez de una imagen que ilustre, como en el meme del asno, un defecto humano tradicionalmente representado mediante ciertas características de un animal, aquí hay siglas o abreviaturas (o, al parecer, la onomatopeya de los zorros al aparearse, según Wikipedia ${ }^{37}$ ) que sugieren que EPN es un animal con apariencia humana - un zorro, que la tradición expone como un ser mentiroso, acomodaticio y poco confiable- especialmente dotado para el sexo, o que consume porno entre furries. $\mathrm{Al}$ parecer, estamos no solo ante un usuario contrario a EPN, sino también ante un reaccionario, pues la otra sigla, "TAF", es el "triple abrazo fraternal" de las logias masónicas al intercambiarse un puesto, lo que implica que el traspaso presidencial entre EPN y

37 En <https://es.wikipedia.org/wiki/Yiff> [Consultado: 30 de octubre de 2018]. 
AMLO, supuestamente encaminado a derribar el régimen clasista e injusto, en realidad es "más de lo mismo".

En tuits como (14), EPN ya no es presentado como el "emperador" (el dios o el tlatoani) que impone su voluntad, sino como aquel que no se ve, el gladiador, pues el gif focaliza en quien decide "sacrificarlo" a pedido del pueblo, el emperador, que una y otra vez, gracias a la animación, hace el gesto del pollice verso (dedo invertido), el cual, como sabemos, está muy extendido en las redes como representación del "no me gusta":
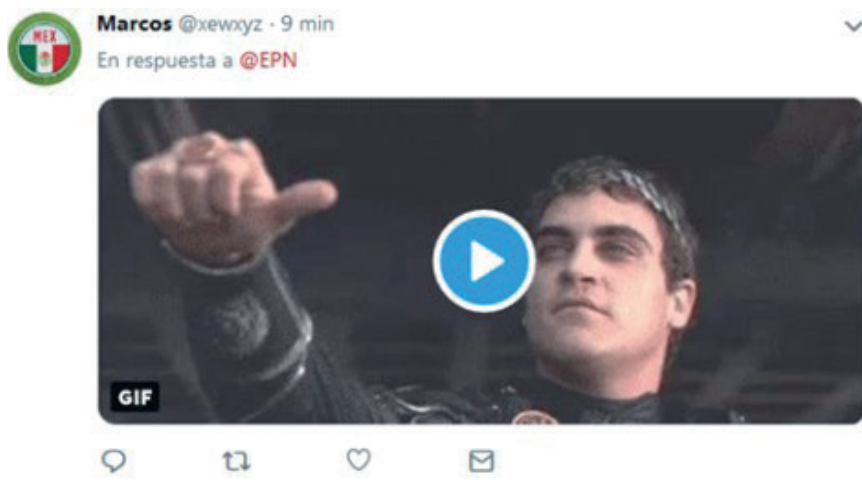

La política también se conecta con la memoria de la catástrofe natural, en la imagen (15), donde se ve a un EPN en el instante mismo de la partida, dejando ruinas a su paso. En la espalda, la huella de una patada lleva a inferir que no se va con honor, sino expulsado por los ciudadanos (o por sus votos, ya que AMLO fue el candidato más votado de la historia). Entre los escombros, un cartelito semihundido recuerda, de modo similar a una lápida, los años de su sexenio (que hoy aparecen en su descripción de Twitter): 2012-2018. Siguiendo a Groarke (2015 y [1996] 2016) y a Haidar (2019), se trata de una argumentación visual, pues la imagen postula una "partida" nada honrosa, que más se parece a un "destierro", la de un EPN representado en el momento mismo de huir, como de un sismo (el nuevo gobierno), con su valijita "de emergencia”: 


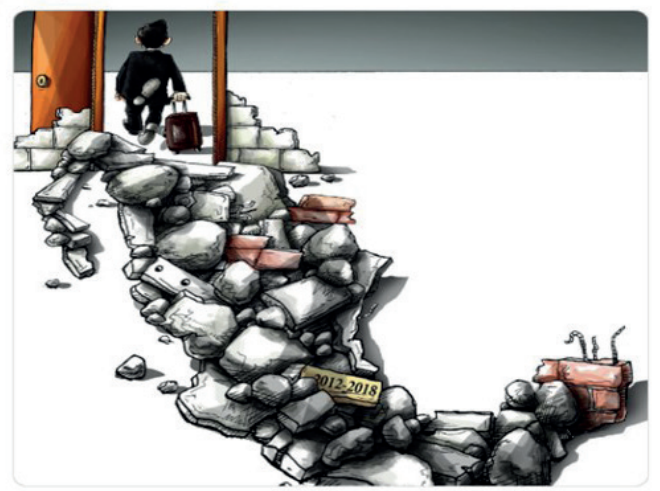

En síntesis, los tuits contra EPN se encaminan a desenmascararlo públicamente. Se construye, así, una imagen de Twitter como arena pública (la del circo romano), pues la cadena polémica plasma una avanzada, la del pueblo, contra quien lo sometió a penurias durante seis años.

\subsubsection{Contra AMLO}

Los tuits contra AMLO no se detienen tanto en el plano moral individual, como ocurre con EPN; antes bien, lo critican a partir del movimiento que lidera, de "regeneración nacional”, cuestionando el hecho de que algo vaya a cambiar realmente con su gobierno (argumentación ad rem: contra sus ideas). Por ello, muchos comentarios sugieren, irónica y humorísticamente, mediante el retruécano, que la "4T" ("Cuarta Transformación”, por el cambio profundo que AMLO pretende con su gobierno, siguiendo la estela de la Independencia, la Reforma y la Revolución ${ }^{38}$ ) es, en realidad, "una transformación de cuarta”, así como una vuelta al pasado, entendido como una época prehistórica o primitiva, cuando no fantástica e ilusoria:

38 Revolución: 1810-1821 (contra los españoles); Reforma: 1858-1861 (separación entre la Iglesia y el Estado, a cargo de Benito Juárez, a quien AMLO admira mucho); Revolución: 1910-1917 (contra el dictador Porfirio Díaz, dio como resultado la promulgación de la Constitución). 
(16)

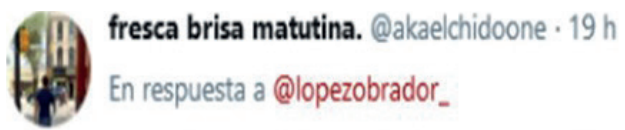

Kemozion, ya en dos días empezará la construcción de carreteras a mano!
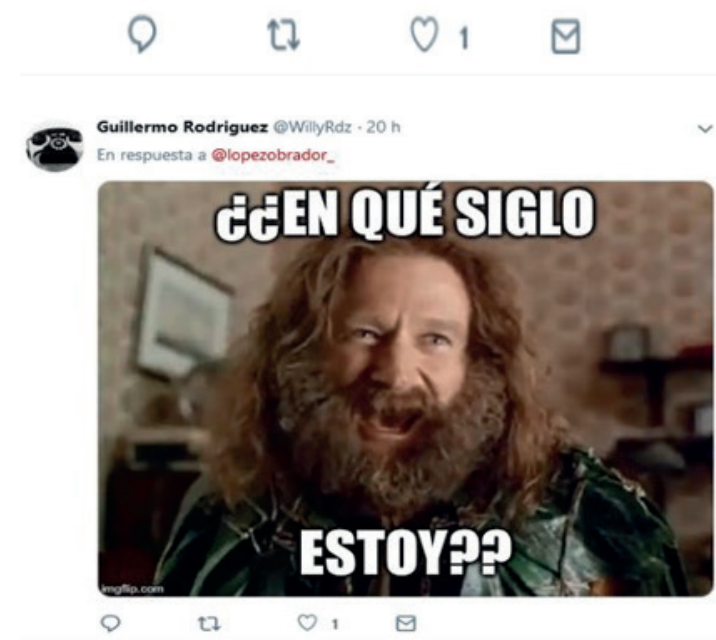

Las ideas revolucionarias, encarnadas en quienes están sentados a la mesa de AMLO (con Rodríguez a la cabeza), son planteadas por los oponentes como vetustas (“de otro siglo”), en tuits que contraponen marcos o expectativas. En la imagen (16), "construcción de carreteras”, no apunta a la modernización, pues la metáfora gramatical "construcción” es precisada por la frase "a mano", que indica que se trata de un proceso primitivo. Al carácter anacrónico del gobierno y de sus idea(le)s apunta el meme del tuit (17), tomado de una secuencia de Jumanji 1 (Joe Johnston 1995), que propicia dos inferencias: por un lado, que el "nuevo" gobierno constituye un desfase temporal o que es producto de la fantasía, y, por otro, que acarrea innumerables calamidades.

Otros tuits, en los que se transmite un acto de regaño o una orden, critican el aspecto idealista del nuevo gobierno, que puede condensarse en la dicotomía u oposición conceptual (Dascal 2008), poesía vs. gestión o realidad vs. fantasía: los tuits equiparan el momento “íntimo” retratado por AMLO como una ficción, "puro verso”. 
Los tuits más violentos cuestionan, además, otro bastión del nuevo gobierno, el de la "austeridad republicana" 39 , a través de una argumentación basada en oposiciones (amigos poderosos/pueblo) y metáforas con connotaciones negativas - subjetivemas valorativos negativos (Kerbrath-Orecchioni 1986)—, como barniz, tertulia entre amigos, mamar del erario (13):

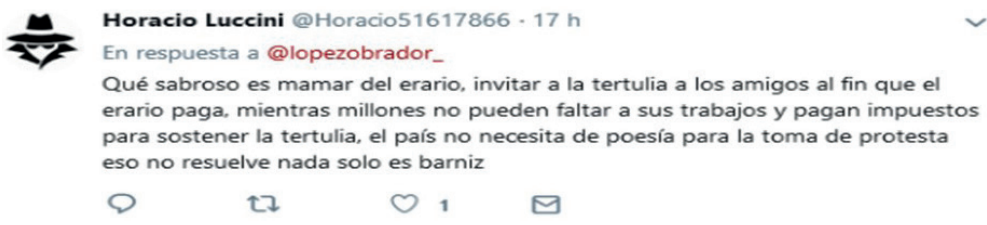

La idea de que el proyecto político es "poesía" se conecta con la matriz del discurso reaccionario y su idea paradójica de que con el cambio nada cambia, cuestión en la que deberemos ahondar en el futuro, pues, en el hilo contra AMLO detectamos huellas de este sistema de creencias consistentes con lo que investigó Hirschman (1989: 86): "Todo cambio es o fue en gran medida apariencia, fachada, cosmético, y por lo tanto ilusorio”, o bien es un peligro para la democracia (con la extensión del Estado), cuando no una perversión: "sostener la tertulia" reproduce el tópico de que el progresismo promociona "la ociosidad" (Hirshman 1989: 99). Vinculados con esta idea, aparecen también otros tuits que, mediante argumentos no entimemáticos contrafácticos, "absurdos o quiméricos" y contrarios a la realidad (Angenot 2016: 46), envestidos de ironía (en su versión de antífrasis), ponen en tela de juicio que haya un cambio, y, para ello, citan al propio AMLO y sus promesas de campaña (entre ellas, las de bajar la gasolina).

La polémica también se manifiesta en la crítica a los colaboradores, consejeros o funcionarios afines a AMLO, como Silvio Rodríguez, Paco Ignacio Taibo II y Daniel Ortega:

\footnotetext{
39 Uno de los tópicos reaccionarios típicos, según Hirschman (1989), o, al menos, uno de los pilares de la derecha. Lo curioso es que el gobierno de AMLO, supuestamente, "progresista”, enarbola como enseña-proyecto la "austeridad republicana".
} 
(19)

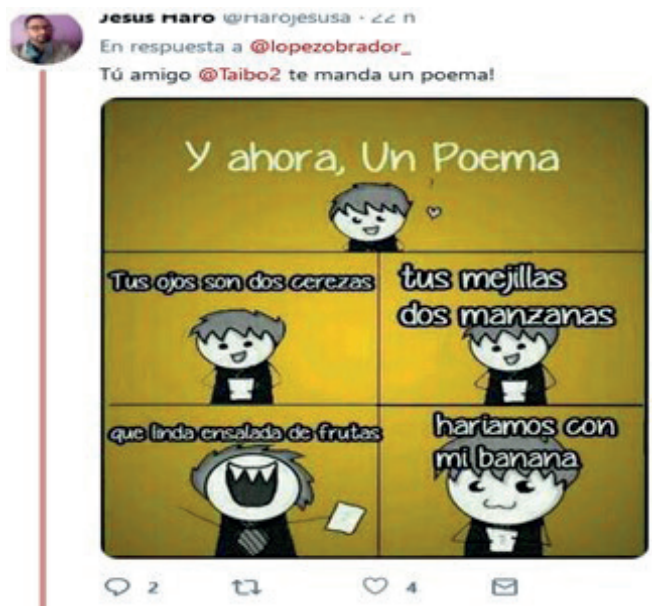

(20)

Siempre19deAbril @Popa2000Nic - $13 \mathrm{~h}$

En respuesta a @lopezobrador_

Y daniel ortega, el asesino de niños entre los presidentes invitados!! Eso dice mucho de su nula solidaridad con los pueblos oprimidos y de su complicidad con los dictadores asesinos de Maduro y FSLN "SOSNICARAGUA

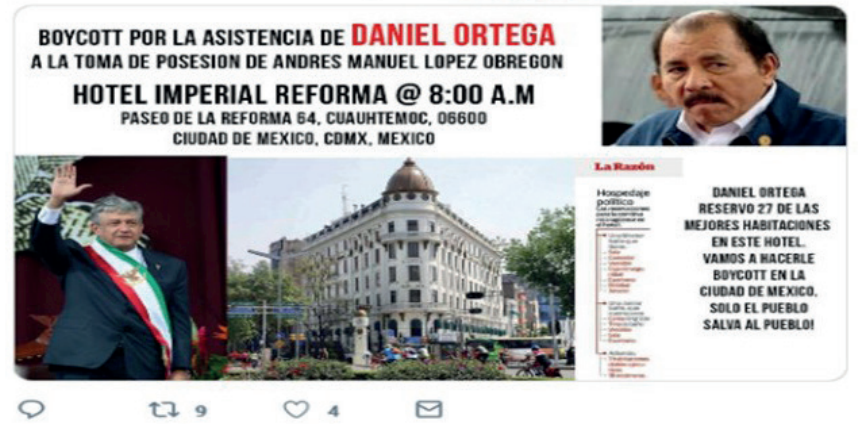

La crítica, en este caso, es más explícita, y se centra en lo moralmente reprobable de "los amigos": la ideología intransigente de Rodríguez, los actos moralmente reprobables de Ortega, el presidente de Nicaragua (al que califican de “asesino de niños”, en lo que es una muestra de "satanización” del contrincante de acuerdo con Angenot 1982 y 2016) y la vulgaridad de Taibo, quien, en la FIL de Guadalajara de 2018, cuando le preguntaron sobre su futuro nombramiento como director del Fondo de Cultura Económica (FCE), 
para el cual se requería la nacionalidad mexicana por nacimiento ${ }^{40}$, manifestó que "va a haber un edicto del presidente nombrándome encargado de despacho mientras sale la ley. Sea como sea se las metimos doblada, camaradas" [las cursivas son nuestras], expresión cuestionada por machista y homofóbica, en que penetrar supone no solo ganar en una contienda (en este caso, política), sino también someter al adversario. Numerosos tuits retoman polifónicamente los dichos de Taibo, por lo general, en modo irónico y, a veces, en la modalidad popular del albur:

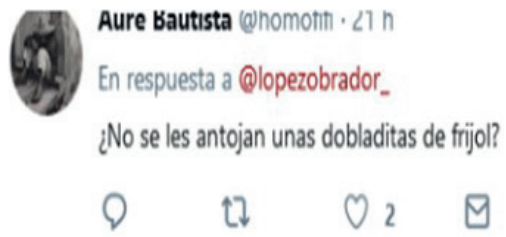

El Diccionario del Español de México define al albur como un "juego de palabras de doble sentido que en una conversación sirve para comentar o responder a algo en plan de burla o escarnio, normalmente, aludiendo a algo que se considera una humillación sexual". Trabajos previos (Mazzuchino 2018, 2019; Sánchez 2019) exploran la posibilidad de un "folkore digital", el cual podría ser producto de la transposición de formas orales tradicionales al ciberespacio. En el caso que nos ocupa, hallamos mensajes con doble sentido, que manifiestan una variante agresiva del humor porque contienen alusiones lúdicas al campo semántico de la penetración masculina desde una perspectiva sexista (Guzmán Díaz 2013: 262263), de modo tal que quien alburea se muestra como el penetrador y no como el penetrado (al igual que en la criticada expresión de Taibo). El humor polémico, especialmente el que se vale del albur, no solo desenmascara al político, sino que lo humilla públicamente.

En (20) resuena el dicho "Dime con quién andas y te diré quién eres": mediante un argumento por analogía, uno de los argumentos

40 El escritor y activista nació en España. 
“no aristotélicos” ni entimemáticos descritos por Angenot (2016: 45), que, según nuestro análisis, son recurrentes en los micropanfletos digitales, se pone en tela de juicio el ethos de hombre honrado de AMLO, por su proximidad con “dictadores" como Ortega (nótese la fuerte descalificación); de ahí la invitación a movilizarse. Lo significativo es que el tuit plantea un "boicot”, término económico que invita a "no comprar" (con el equivalente inglés boycott), y que la convocatoria se fija en el "Hotel Imperial”, lo que genera resonancias de un marco ideológico opuesto al antiimperialista que intenta proyectar AMLO.

Numerosos tuits reproducen una imagen reduccionista del votante morenista o del partido MORENA como "chairo” (según el Diccionario del Español de México, "persona que defiende causas sociales y políticas en contra de las ideologías de la derecha, pero a la que se atribuye falta de compromiso verdadero con lo que dice defender; persona que se autosatisface con sus actitudes" ${ }^{\prime 1}$ ). Otro tipo de argumento ad bominem recurrente consiste en atacar el aspecto físico y la edad del presidente electo y de sus amigos en (22 y 23); en ocasiones, en forma de recomendación que remeda el lenguaje médico (22), de recriminación que cuestiona su capital, esto es, dónde come y sus pertenencias (24), y hasta en forma de juego (25), como encontrar las diferencias con ALIEN: a primera vista, las imágenes son similares por la postura, pero el meme estimula la conclusión de que, como aquel, AMLO es un parásito de la sociedad:

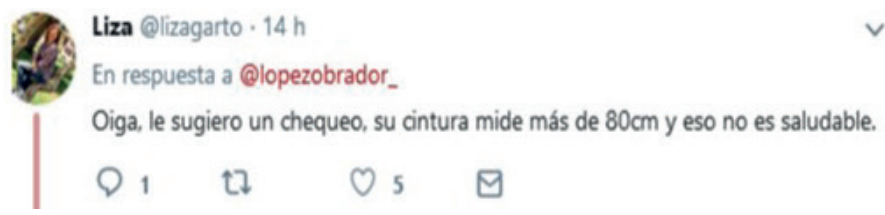

\footnotetext{
41 Villarreal (2014) señala que "chaira” era otro nombre para “chaqueta”, palabra con la que eufemísticamente se conoce en México a la masturbación. Véase <https://www. milenio.com/opinion/rogelio-villarreal/columna-rogelio-villareal/los-chairos> [Consultado: 01 de septiembre de 2019].
} 
En respuesta a @lopezobrador_

Ese asilo esta poca madre, donde es?
Q
t?
$\mathrm{O}_{2}$

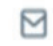

(24)

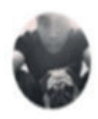

Ede $\odot$ Salinas 0 @eder_salinas7.3 h

En respuesta a @lopezobrador.

En qué fondita comes?? Porque si te alimentan bien chingon, esa panza no es de 50 pesos.... y el reloj tampoco es de gente humilde.

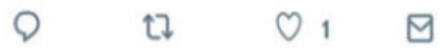

(25)

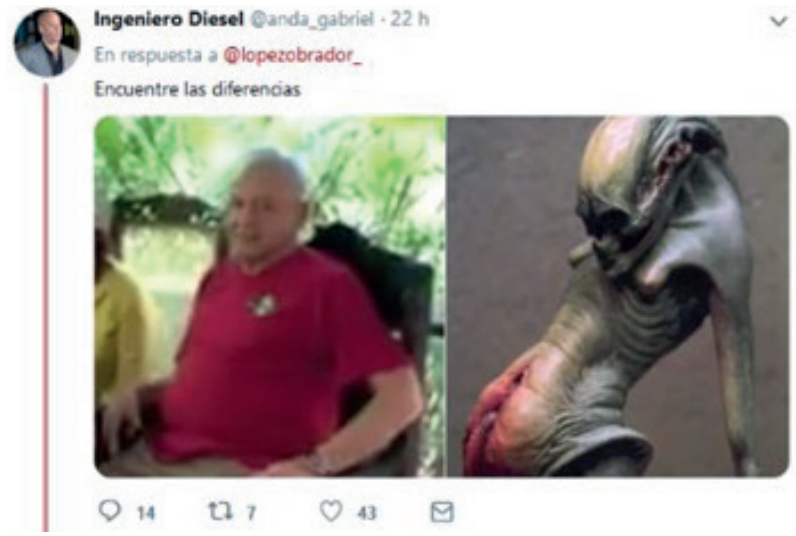

Así, se muestra a AMLO “en contradicción con sus valores y sus referentes” (Bonnafous 2016: 88), sin necesidad de una argumentación explícita, ni tampoco entimemática. La descalificación, que no desdeña groserías (como en el tuit 26, a continuación, en que "LPM" = "la puta madre") ni un trato irrespetuoso (manifiesto en formas coloquiales, como el tuteo), apunta también a la supuesta ineficiencia de AMLO, así como a su ignorancia o lentitud mental; incluso se propone como evidencia de esta contraimagen presidencial la acusación de plagio en al menos uno de sus libros ${ }^{42}$ :

42 En Del esplendor a la sombra: la república restaurada (1988), AMLO habría plagiado a los historiadores Daniel Cossío Villegas y Luis González y González. Véase <https:// 
(26)

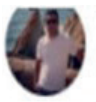

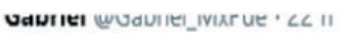

En respuesta a @lopezobrador.

PTM... Todo te tienen que hacer..? No puedes redactarlo tú?

Bueno, lo entiendo si no puedes tomar decisiones de país y tienes que preguntar que hacer... No me sorprende

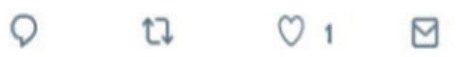

El coaching o "entrenamiento" de Silvio Rodríguez es leído de otro modo por muchos internautas, que conectan esta reunión con las acusaciones de plagio y, por extensión, proyectan una sensación de desconfianza hacia la imagen comprometida, honrada y trabajadora de AMLO, a quien se acusa de "tener que preguntar qué hacer". El tuitero adversario pone en duda que, dadas esas evidencias, AMLO sea capaz de "tomar decisiones de país". Vemos, entonces, que el vituperio no constituye una expresión que anula la argumentación, sino que está al servicio de la oposición (o incluso radicalización) entre posturas, a partir de la denuncia de los vicios del líder.

Por último, hay que destacar un conjunto de tuits que, en cuanto "revisitan" lo popular instaurado por AMLO, matizándolo y recontextualizándolo, generan connotaciones nuevas de los temas musicales de Silvio Rodríguez, y, así, pueden leerse en clave polémica:

Adolfo Müller @_Adolfo_ $17 \cdot 19 \mathrm{~h}$
En respuesta a @lopezobrador_

Se juntaron los astros: Beatriz, Silvio y Andrés; para no hacer de mi fcono pedazos, para salvarme entre únicos e impares, para cederme un lugar en su parnaso.... Para darme un rinconcito en sus altares.

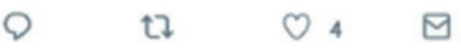

www.elfinanciero.com.mx/opinion/fernando-garcia-ramirez/lopez-obrador-plagiario> [Consultado: 01 de septiembre de 2019]. 


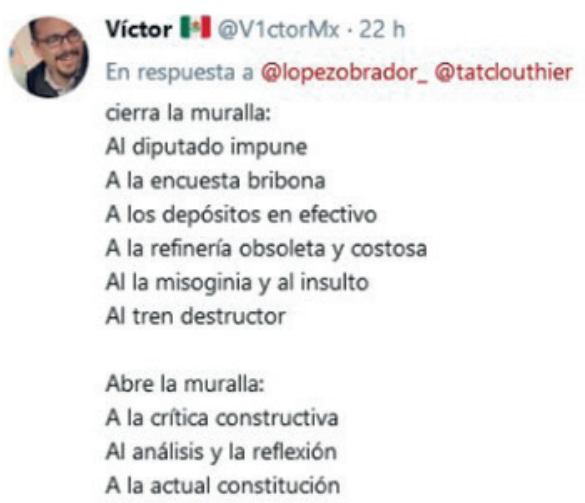

El tuit (27) retoma uno de los "himnos" de la izquierda latinoamericana, que proclama "la necedad de vivir sin tener precio", de mantenerse firme en los propios ideales, compuesto por Silvio Rodríguez en 1991, en el marco de la incertidumbre por la caída de la Unión Soviética. Pero el tuitero retoma estos versos atribuyéndolos no ya a quienes "invitan" a la voz lírica a traicionarse, sino a los que están sentados a la mesa de AMLO, años después, con lo que subvierte la situación inicial e introduce un marco nuevo, que le endilga a la izquierda la imagen de algo divino o inaccesible y, por tanto, alejado del pueblo o de la realidad (porque astros, su parnaso, sus altares se refieren a AMLO y sus amigos). Esta representación, en sintonía con la crítica de Baudrillard (1985) de la gauche divine - entre otras cosas, por su espectacularización y su pretendida virtud-, puede ser también otra traza del pensamiento reaccionario en el corpus (Hirshman 1989), además de ser otra muestra de argumentación no entimemática; esta vez, basada en tropos como la metáfora (Angenot 1982: 249; Bonnafous 2016: 90-91).

El tuit (28) es más explícito, pues no solo recontextualiza el poema de Guillén, sino que sustituye las oposiciones instauradas por el poeta (nombres simples que remiten a lo malo que hay que dejar fuera del proyecto popular y a lo bueno que hay que dejar entrar) por palabras que aluden a propuestas de AMLO: encuesta, refinería, tren, diputado impune o insulto, por sus promesas de campaña, algunas de ellas muy cuestionadas, como el tren maya o la 
refinería de Dos Bocas; las consultas populares, como la que llevó adelante para decidir si continuar o no con el aeropuerto insignia del PRI, el de Texcoco, o bien empezar a construir otro, el de Santa Lucía (opción ganadora); los funcionarios acusados de corrupción en gestiones anteriores, con los que se alió, y los dichos de Taibo, que aparecen en la cadena de tuits en otros tramos, como vimos.

Imitando a Guillén, el enunciador del tuit enlista nombres de realidades que estima positivas para el nuevo gobierno, y que presupone que le faltan (o que "dejó afuera” de la muralla, siguiendo con la imagen poética): la crítica constructiva, el análisis y la reflexión, y la actual constitución, pues en la opinión pública circula(ba) el temor de que AMLO modificara la carta magna y de que abriera la posibilidad de la reelección, lo que, como sabemos, es rechazado por la ciudadanía desde el famoso lema de la revolución de Francisco I. Madero contra Porfirio Díaz: "Sufragio efectivo. No reelección”. Lo interesante es que AMLO se presenta como un acérrimo opositor del porfiriato, cuyos males proyecta hoy en la clase privilegiada (los “fifís”).

\section{Palabras finales}

¿Qué "lugares" visitan hoy las “voces marginales" para denunciar e indignarse? Más que el "ágora pública moderna” (Gallardo-Paúls 2017: 191), Twitter se ha convertido en el sucedáneo de la "tertulia marginal” que describió Rojas (1997, 2003) para los panfletistas decimonónicos mexicanos, o incluso, si se alcanzan cotas más altas de acrimonia, en la "arena” de la discusión pública. El espíritu del panfleto parece esa "marca de agua” a través de los siglos de la que habla Hastings (2009), al advertir que es mucho más antiguo que los textos de la época de oro descrita por Angenot (1982), y al vislumbrar la posibilidad de que el género emerja hoy en las redes sociales, hipótesis que validamos en estas páginas, si bien algunos aspectos (como los ligados a la multimodalidad, a la argumentación visual o a los rasgos del panfleto tradicional) podrían ser objeto de un análisis más exhaustivo. 
En los "micropanfletos" digitales — como llamamos a los tuits adversos a EPN y a AMLO-, aflora una voz irreverente que conjuga recursos de vieja data, como el humor, la ironía, la sátira, la parodia y las figuras de vehemencia, con el fin de descalificar al político, exhibiendo su impostura o ineptitud, para hacerlo objeto del escarnio público, de modo similar al panfleto del siglo XIX, pero sin riesgo para la vida ni temor a un "juicio de imprenta" (Picatto 2003).

A diferencia de su antecesor, sometido a fuertes "mecanismos de control y represión” (Rojas 1997: 60), el micropanfleto digital fluye sin ataduras por la red y sin necesidad de resguardarse bajo un pseudónimo: así, el ciudadano común y corriente se erige como el nuevo panfletista, esa figura solitaria que reclama su momento "para decir", un decir que es denunciar al poder, pero que, como antes, también es desazón y resistencia. Se borran, así, los límites entre lo público y lo privado, y el sujeto ejerce su "derecho de ser diferente" y de decir "su" verdad, que puede ser rápidamente replicada por otros con "un espíritu de juego que desdramatiza la violencia de las palabras" (retomando a Garand 2016: 135).

$\mathrm{El}$ análisis discursivo revela que los tuits contrarios a EPN son más vitriólicos, quizá por los años "de fiesta" para unos pocos, los de su sexenio, y por el hecho de que la fiesta popular a la que invita AMLO (a partir de un poema esperanzado de Guillén) recién estaba comenzando. La "toma de protesta" de este último (jurar, en sentido laico) se convierte en la oportunidad para que los ciudadanos "protesten", en el sentido de quejarse, y muestren su "coraje", no como valentía o parresia, sino como el mexicanismo hacer coraje: "Sentimiento de enojo y rabia intensa, a veces contenido y a veces expresado con actos agresivos y violentos, generalmente provocado por algo que se considera injusto o que contraría los deseos propios" (Diccionario del Español de México).

Sea cual fuere su adscripción ideológica o el político al que siguen, devenido en antagonista, los tuits se valen de una argumentación no siempre entimemática, similar a la del panfleto tradicional, un género que está más vivo que nunca y que, como hace poco más de un siglo atrás, al enfrentar al poderoso en pie de igualdad -al menos, desde la palabra-, enfrenta al silencio. 


\section{Referencias bibliográficas}

Alonso, Paula

2003 “Introducción”. En Construcciones impresas. Panfletos, diarios y revistas en la formación de los Estados nacionales en América Latina, 1820-1920. México: Fondo de Cultura Económica, 3-8.

Amossy, Ruth

2011 "La coexistence dans le dissensus. La polémique dans les forums de discussion”. SEMEN. Eds., Ruth Amossy y Marcel Burguer. 31. 125-42. Consultado: 13 de noviembre de 2018. <https://journals.openedition.org/semen/9051>

Amossy, Ruth

2016 "Por una retórica del dissensus: las funciones de la polémica". En El análisis del discurso polémico. Disputas, querellas y controversias. Comp., Ana Soledad Montero. Buenos Aires: Prometeo, 25-38.

Amossy, Ruth

2017 Apología de la polémica. Buenos Aires: Prometeo.

Amossy, Ruth, y Marcel Burguer

2011 “Introduction: la polémique médiatisée”. SEMEN. Polémiques médiatiques et journalistiques. 31. 7-24. Consultado: 13 de noviembre de 2018. <https://doi.org/10.4000/semen.9072>

Angenot, Marc

1982 La parole pamphlétaire. Contribution à la typologie des discourse modernes. Payot, París.

ANGENOT, Marc

2016 “Diálogo de sordos. Tratado de retórica antilógica”. En El análisis del discurso polémico. Disputas, querellas y controversias. Comp., Ana Soledad Montero. Buenos Aires: Prometeo, 39-53.

Arnoux, Elvira

2006 Análisis del Discurso. Modos de abordar materiales de archivo. Buenos Aires: Santiago Arcos. 
Arnoux, Elvira y María Imelda Blanco

2007 "Cita, comentario y reformulación en la travesía de un fragmento del Nuevo Testamento". Tópicos del Seminario. 17, 63-87. Consultado: 19 de mayo de 2020. <http://www.scielo. org.mx/pdf/tods/n17/2594-0619-tods-17-63.pdf>

BAJTín, Mijaíl

1987 La cultura popular en la Edad Media y el Renacimiento. El contexto de François Rabelais. Madrid: Alianza Editorial.

Balbuena, Fiorella

2014 "Comentario de texto lírico «La muralla»". Consultado: 01 de enero de 2018. <https://webcache.googleusercontent.com/search?q=cache:SPoe_ouKby8J:https:// lenguayliteraturacic.weebly.com/uploads/1/5/7/2/15727512/ comentario_de_texto_lrico_ $1_{-} l_{a_{-}}$muralla. $\mathrm{docx}+\& \mathrm{~cd}=48 \& \mathrm{chl}=\mathrm{es}-419 \& \mathrm{ct}=\mathrm{clnk} \& \mathrm{gl}=\mathrm{mx}>$

BAUdRILLARD, Jean

1985 La izquierda divina. Barcelona: Anagrama.

BonnAFous, Simone

2016 "El arma de la burla en J.-M. Le Penn”. En El análisis del discurso polémico. Disputas, querellas y controversias. Comp., Ana Soledad Montero. Buenos Aires: Prometeo, 85-95.

Cantamutto, Lucía y Cristina Vela Delfa

2016 "El discurso digital como objeto de estudio: de la descripción de interfaces a la definición de propiedades”. Aposta Revista de Ciencias Sociales. Monográfico de discurso digital. 69, 296-323. Consultado: 28 de agosto de 2017. <https:// www.researchgate.net/publication/299506713_El_discurso_ digital_como_objeto_de_estudio_de_la_descripcion_de_ interfaces_a_la_definicion_de_propiedades>

Cantamutto, Lucía y Cristina Vela Delfa

2020 "Mensajes, publicaciones, comentarios y otros textos breves de la comunicación digital". Tonos Digital. Revista de estudios filológicos. 38. 1-27.

CARlón, Mario

2016 "Registrar, subir compartir. Prácticas fotográficas en la era contemporánea”. En Actas V Simposio Internacional de 
Estética: estética, medios y subjetividades. Santiago de Chile: Pontificia Universidad Católica, 31-54.

Carvajal Barrios, Giovanna

2017 Chat, Facebook y Twitter. Transformaciones de la cultura escrita en el ciberespacio. Colombia. Universidad del Valle.

Cediel, Yulia, y Giohanny Olave

2018 "Insulto y política en el discurso divergente: el caso de las FARC-EP”. Cuadernos De Lingüística Hispánica. 33. 86-106. Consultado: 08 de agosto de 2018. <https://doi. org/10.19053/0121053X.n33.2019.8951>

Charaudeau, Patrick

2009 "Análisis del discurso e interdisciplinariedad en las ciencias humanas y sociales". En El discurso y sus espejos. Ed., Luisa Puig. Ciudad de México: Universidad Nacional Autónoma de México, 99-133.

Charaudeau, Patrick y Dominique Maingueneau

2005 Diccionario de análisis del discurso. Buenos Aires: Amorrortu.

Courier, Paul Louis

1936 Panfletos políticos 1816-1821. Madrid: Revista de Occidente.

DASCAL, Marcelo

2008 "Dichotomies and types of debates". En Controversy and Confrontation. Eds., Frans H. van Eeemeren y Bart Garssen. Amsterdam/Philadelphia: John Benjamins, 27-49.

FANDUZzi, Natalia Paula

2008 "Panfleto político". En Diccionario del Pensamiento Alternativo II. Dirs., Hugo E. Biagini y Arturo Roig. Buenos Aires: Biblos y Centro de Ciencia, Educación y Sociedad (CECIES). Consultado: 20 de junio de 2020. <http://www.cecies.org/ articulo.asp? $\mathrm{id}=136>$

Foucault, Michel

1973 El orden del discurso. Barcelona: Tusquets Editores.

Foucault, Michel

2017 Discurso y verdad. Conferencias sobre el coraje de decirlo todo. Grenoble, 1982 / Berkley, 1983. Buenos Aires: Siglo XXI Editores. 
Fraticelli, Damián

2019 "Los colectivos mediáticos de las redes. Algunas observaciones desde el humor ¿y más allá? InMediaciones de la Comunicación. 14. 1, 47-63. Consultado: 02 de enero de 2020. <https:// doi.org/10.18861/ic.2019.14.1.2885>

Fuchs, Catherine

1994 Paraphrase et énonciation. París: Ophrys.

Gallardo-Paúls, Beatriz

2017 "Pseudopolítica en la red: indicadores discursivos de desideologización en Twitter”. Pragmalingüistica. 25. 189-210. Consultado: 2 de agosto de 2018. <https://doi.org/10.25267/ Pragmalinguistica.2017.i25.10>

GANTús, Fausta

2009 Caricatura y poder político. Crítica, censura y represión en la ciudad de México, 1876-1888. México: El Colegio de México.

GARAND, Dominique

2016 "La función del ethos en la formación del discurso conflictivo". En El análisis del discurso polémico. Disputas, querellas y controversias. Comp., Ana Soledad Montero. Buenos Aires: Prometeo, 123-137.

GenETTE, Gerard

[1972] 1989. Figuras III. Barcelona: Lumen.

Gómez Álvarez, María Cristina, y Mariana Ozuna Castañeda 2015 Informe "El libro y el folleto en el proceso de transición: Nueva España (1750-1820)". Programa de Apoyo a Proyectos de Investigación e Innovación Tecnológica. Consultado: 22 de septiembre de 2019. <https://dgapa.unam.mx/images/ papiit/transparencia/proyxanio/2018/IN400215_Informe_ Final_2015.pdf>

GonzÁlez Doreste, Dulce

1993 "Notas (hipertextuales) sobre la parodia genettiana: a propósito de Palimpsestos. Revista de Filología de la Universidad de La Laguna. 212, 83-103.

GoudeT, Laura

2016 "Le dispositif iconotextuel des mèmes: clichés variables et subversion des genres”. Fragmentum. Hal. Archives-ouvertes. 
1-24. Consultado: 18 de septiembre de 2019. <https://hal. archives-ouvertes.fr/hal-02118791/document>

Groarke, Leo

2015 "Going Multimodal: What is a Mode of Arguing and Why Does It Matter?”. Argumentation. 29. 2, 133-155. Consultado: 17 de noviembre de 2017. <https://doi.org/10.1007/s10503014-9336-0>

Groarke, Leo

[1996] 2016 "Informal Logic". En Stanford Encyclopedia of Plilosophy. Stanford: Stanford University Press. Consultado: 17 de noviembre de 2019. <https://plato.stanford.edu/entries/logicinformal/>

Gutiérrez, Silvia, y Christian Plantin

2010 "Argumentar por medio de las emociones: la «campaña del miedo» del 2006”. Revista Versión. Estudios de Comunicación y Política. 24, 41-69. México: UAM, Xochimilco. Consultado: 20 de junio de 2018. <https://versionojs.xoc.uam.mx/index. $\mathrm{php} / \mathrm{version} / \mathrm{article} / \mathrm{view} / 375>$

GuZmán Díaz, Josefina

2013 "Yo locoloco y ella loquita. Análisis semiótico argumentativo del uso del albur en la publicidad". En La argumentación. Ensayos de análisis de textos verbales y visuales. Coords., Adrián Gimate Welsh y Julieta Haidar. Ciudad de México: Universidad Autónoma Metropolitana, 261-284.

HAIDAR, Julieta

2019 “Argumentación visual/emocional: modelos analíticos". En Discurso, cultura, emoción; prácticas discursivas interculturales, transculturales y alternativas, de María Eugenia Treviño, Julieta Haidar, Clara Rojas Blanco y Ernesto De los Santos. Asociación Latinoamericana de Estudios del Discurso, 3-30. Consultado: 17 de octubre de 2018. <https://www.academia. edu/40199584/Argumentaci\%C3\%B3n_visual_emocional_ modelos_anal\% $\mathrm{C} 3 \% \mathrm{ADticos}>$

Hastings, Michel

2009 "De la vitupération. Le pamphlet et les régimes du «dire vrai» en politique”. En Mots. Les langages du politique. Dirs., Michel Hastings, Cédric Passard y Juliette Rennes. 35-49. 
Consultado: 24 de julio de 2019. <https://doi.org/10.4000/ mots.19188>

Helfrich, Uta

2014 "FACE-WORK AND FLAMING IN SOCIAL MEDIA". EN Face work and social media. Eds., K. Bedijs, G. Held y C. Maan. Münster: LIT-Verlag, 297-321.

Herring, Susan

2004 "Computer-mediated discourse análisis: an approach to researching online communities". En Designing for Virtual Communities in the Service of Learning. Eds., S.A. Barab, R. Kling y J. H. Gray. 1-35 [338-376]. Versión prepint compartida por la autora. Consultado: 12 de mayo de 2020. <https:// www.researchgate.net/publication/285786435_Computermediated_discourse_analysis_an_approach_to_researching online_communities>

Hirschman, Albert O.

1989 "Doscientos años de retórica reaccionaria. El caso del efecto perverso”. El Trimestre Económico. 56. 221(1), 81-105.

Husson, Anne-Charlotte

2016 "Les hashtags militants, des mots-arguments". Fragmentum. 48, 105-127. Consultado: 05 de octubre de 2019. <https:// periodicos.ufsm.br/fragmentum/article/view/23295>

Jost, François

2019 "Le web 2.0: une nouvelle trajectoire pour la sémiologie audiovisuelle ?". En Trayectorias. $14^{\circ}$ Congreso Mundial de Semiótica. Buenos Aires: IASS/AIS.

Kaul, Silvia, y Ariel Cordisco

2014 "La descortesía verbal en el contexto político-ideológico de las redes sociales". Revista de Filología de la Universidad de la Laguna. 32, 145-161. Consultado: 01 de marzo de 2016. <https://riull.ull.es/xmlui/handle/915/4645>

Kerbrath-Oreccioni, Catherine

1986 La enunciación. De la subjetividad en el lenguaje. Buenos Aires: Hachette. 
LE BART, Christian

2009 "Le pamphlet politique aujourd'hui. Une catégorie honteuse?”. Mots. Les langages du politique. Que devient le pamphlet? Dirs., Michel Hastings, Cédric Passard et Juliette Rennes. 91, 67-81. Consultado: 24 de julio de 2019. <https:// doi.org/10.4000/mots.19217>

Mancera Rueda, Ana, y Ana Pano Alamán

2013a El español coloquial en las redes sociales. Madrid: Arco/Libros.

Mancera Rueda, Ana y Ana Pano Alamán

2013b El discurso político en Twitter. Análisis de mensajes que "trinan". Barcelona: Anthropos.

Matallana, Andrea

1999 Humor y política. Un estudio comparativo de tres publicaciones de bumor politico. Buenos Aires: Eudeba.

Mazzuchino, María Gabriela

2018 "Entre la agresión y la reivindicación: ironía, paodia y sátira en comentarios al Facebook del presidente mexicano". Romanica Olomucensia. 2, 191-216. Consultado: 01 de febrero de 2018. <http://romanica.upol.cz/artkey/rom-201802-0002_entrela-agresion-y-la-reivindicacion-ironia-parodia-y-satira-encomentarios-al-facebook-del-presidente-mexic.php>

Mazzuchino, María Gabriela

2019 "El discurso político digital. Humor y polémica en Facebook”. Pragmalingüística. 27, 191-211. Consultado: 3 de enero de 2020. <https://doi.org/10.25267/Pragmalinguistica.2019. i27.10>

Metz, Christian

1885 "Photography and fetish". October. 34, 81-90. Consultado: 1 de junio de 2020. <https://www.jstor.org/stable/pdf/778490. pdf?casa_token=H6_58dwpkzUAAAAA:xZGvPk5L22dSgL eUlKtWVyf_-h-xV3FHSwJAuRSAUjmOZdS2oDbGEnUibmjSUQH1VlWlaqrESdXKNxq_oio_syxo4JqkEd5UnFurHIHhM2KZ29qpfUVZ5g>

Olave, Giohanny

2019 Análisis del discurso en disputas públicas. Retorno a la erística. Colombia: Universidad Industrial de Santander. 
Palti, Elías

2003 "Los diarios y el sistema político mexicano en tiempos de la República Restaurada (1867-1876)”. En Construcciones impresas. Panfletos, diarios y revistas en la formación de los Estados nacionales en América Latina, 1820-1920. Comp., Paula Alonso. México: Fondo de Cultura Económica, 167181.

Pano Alamán, Ana, y Ana Mancera Rueda

2014 "Identidades falsas en Twitter: la ironía y el humor verbal como mecanismos paródicos". Discurso E Sociedad. 8. 3, 507536.

PARdo, María Laura, y María Valentina Noblía

2015 "Ni diálogo ni debate: la voz de la audiencia en los comentarios digitales sobre la pobreza. RALED. Revista Latinoamericana de Estudios del Discurso. 15. 2, 117-137. Consultado: 28 de agosto de 2018. <https://doi.org/10.35956/v.15.n2.2015.p.117-137>

Paveau, Anne-Marie

2013 "Hashtag". Technologies discursives. s/p. Consultado: 10 de octubre de 2018. <http://technodiscours.hypotheses.org/488>

2015 "Ce qui s’écrit dans les univers numériques. Matières technolangagières et formes technodiscursives”. Itinéraires. Littérature, Textes, Cultures. 1-12. Consultado: 11 de noviembre de 2018. $<$ https://hal.archives-ouvertes.fr/hal-00990029/document>

Picatto, Pablo

2003 "Jurados de imprenta en México: el honor en la construcción de la esfera pública, 1821-1882”. En Construcciones impresas. Panfletos, diarios y revistas en la formación de los Estados nacionales en América Latina, 1820-1920. Comp., Paula Alonso. México: FCE, 139-165.

Plantin, Christian

2004 "Pensar el debate". Revista Signos. 37. 55, 121-129. Consultado: 20 de enero de 2017. <https://dx.doi.org/10.4067/ S0718-09342004005500010>

Plantin, Christian

2012 "Argumentar y manipular para probar". En Lenguaje y educación: perspectivas metodológicas y teóricas para su estudio. Ed., Sandra Soler Castillo. Colombia: Universidad Distrital 
Francisco José de Caldas, 105-129. Consultado: 05 de mayo de 2018. <https://hal.archives-ouvertes.fr/halshs-00990030>

Plantin, Christian

2016 "De polemistas a polemizadores". En El análisis del discurso polémico. Disputas, querellas y controversias. Comp., Ana Soledad Montero. Buenos Aires: Prometeo, 25-38.

Qués, María Elena

2019 ¿Qué se teje en la red? El debate sobre YPF en Facebook y Twitter. Islas Mauricio: Editorial Académica Española.

Rojas, Rafael

1997

"Una maldición silenciada. El panfleto político en el México independiente". Historia Mexicana. XLVII. I, 35-67. Consultado: 28 de agosto de 2018. <https://historiamexicana.colmex. $\mathrm{mx} /$ index.php/RHM/article/view/2426/1948>

RojAs, Rafael

2003 La escritura de la Independencia. El surgimiento de la opinión pública en México. México: Taurus \& CIDE.

Rojas, Rafael

2010 "El debate de la Independencia. Opinión pública y guerra civil en México (1808-1830)". En Documentos de rabajo del CIDE. México: CIDE, 4-24. Consultado: 28 de agosto de 2018. <http://www.libreriacide.com/librospdf/DTH-67.pdf>

Sal Paz, Julio César

2016 "El comentario digital como género discursivo periodístico. Análisis de La Gaceta de Tucumán”. Aposta. Revista de Ciencias Sociales. Monográfico Análisis del Discurso Digital. 69. 158-216. Consultado: 12 de mayo de 2020. <https://www. redalyc.org/jatsRepo/4959/495952431007/html/index.html>

SAlerno, Paula

2018 "Discurso polémico e interacción en Twitter y comentarios digitales: el caso de Malvinas durante el último gobierno de CFK”. RALED. Revista Latinoamericana de Estudios del Discurso. 18. 1, 4-22. Consultado: 30 de agosto de 2018. <https:// doi.org/10.35956/v.18.n1.2018.p.4-22> 
SÁNCHEZ, Sandra

2019 "Folklore digital, prosumidores y creepypasta". En Trayectorias. $14^{\circ}$ Congreso Mundial de Semiótica. Buenos Aires: IASS/ AIS.

SCHOPEnHAuer, Arthur

[1830] 1997 Dialéctica erística o el arte de tener razón expuesta en 38 estratagemas. Madrid: Editorial Trotta.

ScOlari, Carlos

2009 "Formatos breves, microrrelatos y otros nanosaurios". En Hipermediaciones. Consultado: 01 de agosto de 2019. <https:// hipermediaciones.com/2009/10/21/formatos-breves-microrrelatos-y-otros-nanosaurios/>

ScOlari, Carlos

2019 "No nos transforma el contenido de un libro, sino el mismo acto de leerlo". La Nación. Consultado: 10 de diciembre de 2019. <https://www.lanacion.com.ar/opinion/carlos-scolarino-nos-transforma-contenido-libro-nid2296483>

Silva-Herzog, Jesús

2017 "El panfleto frente al temperamento ramical”. Nexos. 39. 475. Consultado: 20 de enero de 2018. <https://www.nexos.com. $\mathrm{mx} / \mathrm{p}=32818>$

Slimovich, Ana

2012 "Apuntes sobre las discursividades políticas en el Facebook de Mauricio Macri”. Revista Tram[p]as de la comunicación y la cultura 72, 1-8. Consultado: 07 de diciembre de 2018. <http:// sedici.unlp.edu.ar/handle/10915/34797>

Slimovich, Ana

2018 "El metacuerpo presidencial: los internautas ciudadanos, seguidores y opositores". Revista Bordes, 1-12. Consultado: 07 de diciembre de 2018. <http://revistabordes.com.ar/lapolitica-en-instagram/>

Standage, Tom

2013 Writing on the Wall: Social Media. The First 2,000 Years. Nueva York: Bloomsbury. Edición Kindle. 
Toulmin, Stephen

[1958] 2003 The Uses of Argument. Cambridge: Cambridge University Press.

Ventura, Aniela

2018 “Cómo analizar discursos de 140 caracteres? Propuesta metodológica para el estudio del discurso político de campaña en Twitter a partir del análisis estratégico del discurso con una perspectiva multimodal y crítica". Chimera: Romance Corpora and Linguistics Studies. 5. 2, 275-287. Consultado: 22 de agosto de 2018. <https://doi.org/10.15366/chimera2018.5.2.006>

Walton, Douglas

1989 Informal Logic: A Handbook for Critical Argumentation. New York: Cambridge University Press.

Walton, Douglas

1992 Plausible Argument in Everyday Conversation. Albany: State University of New York Press.

Yus, Antonio

2001 Ciberpragmática. El uso del lenguaje en Internet. Barcelona: Ariel.

Yus, Antonio

2018 "Identity-related issues in meme communication". Internet Pragmatics. 1. 1, 113-133. Consultado: 01 de noviembre de /2019. <https://doi.org/10.1075/ip.00006.yus>

Recepción: 25/11/2019 Aceptación: 01/06/2020 